УДК 547.972

\title{
СТРУКТУРНОЕ РАЗНООБРАЗИЕ И СТЕПЕНЬ ИЗУЧЕННОСТИ ФЛАВОНОИДОВ РОДА SCUTELLARIA L.
}

\author{
() А.М. Каримов ${ }^{1,2}$, Э.Х. Ботиров ${ }^{3 *}$ \\ ${ }^{1}$ Институт химии растительных веществ им. акад. С.Ю. Юнусова, АН РУз, \\ ул. Мирзо Улугбека, 77, Ташкент, 700170 (Республика Узбекистан) \\ ${ }^{2}$ Наманганский государственный университет, ул. Уйчи, 316, Наманган, \\ 716001 (Республика Узбекистан), e-mail: abdurashidka@mail.ru \\ ${ }^{3}$ Сургутский государственный университет, ул. Ленина, 1, Сургут, 628412 \\ (Россия), e-mail: botirov-nepi@mail.ru
}

В обзоре приведены результаты наукометрического анализа данных по степени изученности и хеморазнообразию флавоноидов видов рода Scutellaria L. мировой флоры. Представлена информация о составе флавоноидов 63 видов Scutellaria, о распространении в растениях, структуре и источниках получения 301 флавоноида, относящегося к группам флавонов, флаванонов, флаванонолов, флавонолов, халконов, изофлавонов, флаволигнанов и бифлавоноидов. Показано, что наибольшее количество флавоноидов было выделено из S. baicalensis, S. indica, S. barbata, S. amoena, S. prostrata, S. galericulata, S. discolor, S. ramosissima и S. иріna. Наукометрические исследования свидетельствуют о постоянно растущем интересе к изучению видов рода Scutellaria L. со стороны ученых - фитохимиков, биологов, фармакологов и др. Приведенные в обзоре сведения могут быть использованы для решения вопросов хемосистематики растений рода Scutellaria L.

Ключевые слова: Scutellaria L., Lamiaceae, флавоноиды, наукометрический анализ, хеморазнообразие.

Сокращения: ЯMP - ядерный магнитный резонанс, Glcp - $\beta$-D-глюкопиранозид, Galp - $\beta$-D-галактопиранозид, $G l c A p$ - $\beta$-D-глюкуронопиранозид, GalAp - $\beta$-D-галактуронопиранозид, Arap - $\alpha$-L-арабинопиранозид, Rhap - $\alpha$-Lрамнопиранозид, $M e$ - метил, $E t$-этил, $A c$ - ацетил, $p-H b z$ - n-гидроксибензоил, Van - ванилоил, Caf - кафеоил, Fer ферулоил, Sin - синапоил.

Растения рода Scutellaria L. (семейство Lamiaceae) на земном шаре представлены 360 видами и широко распространены в умеренных, субтропических и тропических регионах, включая Европу, Северную Америку и Восточную Азию [1-4]. Родовое наименование Scutellaria генетически связано с латинскими scutum (щит) и scutellum (щиток) и указывает на форму придатка верхней части чашечки у большинства видов рода. Русский термин «шлемник» соответствует старому названию рода Cassida (от лат. cassida шлем). На территории стран СНГ произрастают около 120 (по некоторым данным 148) видов с подвидами, главным образом в горах Кавказа и Средней Азии. Шлемники - многолетние или, очень редко, однолетние травы, изредка полукустарники или кустарнички. Многие виды шлемника декоративны, некоторые - лекарственные растения, но все они относится к числу красильных трав.

Цель настоящей работы - обобщение сведений научной литературы о химическом составе флавоноидов видов рода Scutellaria L.

Химический состав растений рода Scutellaria L. разнообразен, и к настоящему времени из видов данного рода выделены флавоноиды, фенилпропаноиды, фенолокислоты, иридоиды, дитерпеноиды клеро-

Каримов Абдурашид Мусахонович - докторант кафедры химии, e-mail: abdurashidka@mail.ru

Ботиров Эркин Хожсакбарович - заведующий кафедрой химии, доктор химических наук, профессор, тел. (3462) 76-30-91, e-mail: botirov-nepi@ mail.ru данового ряда, стероиды, тритерпены, лигнаны, алкалоиды, фитостерины, полисахариды, дубильные вещества, эфирные масла и другие классы природных веществ [4, 8-10, 13].

\footnotetext{
* Автор, с которым следует вести переписку.
} 
Химическое исследование флавоноидов растений рода Scutellaria L. начинается с 1910 г., когда из S. altissima был выделен флавоноид скутеллареин [8].

Растения этого рода широко используются в народной медицине в течение тысяч лет [4-8]. Корни S. baicalensis и трава $S$. barbata включены в фармакопеи Китая и Японии [7, 8]. Надземная часть S. galericulata в народной медицине Сибири применяется при тошноте, диспепсии, желудочно-кишечных расстройствах, при гипертоническеой болезни, асците, малярии, кровотечениях и острых респираторных инфекциях $[4,9]$. Надземная часть S. scordifolia в тибетской медицине применяется при пневмонии, миокардитах, тахикардии, полиартрите, как жаропонижающее, а в народной медицине Бурятии - при желудочно-кишечных заболеваниях, почечных и печеночных коликах, малярии, анорексии [4, 8, 10, 11]. В Фармакопее США высушенная надземная часть $S$. lateriflora рекомендуется в качестве успокоительного и спазмолитического средства для лечения эпилепсии, нервного возбуждения, невралгии [8].

Наибольшее значение имеет S. baicalensis, встречающийся в восточном Забайкалье, среднем Приамурье и юго-западном Приморье [12]. Корни S. baicalensis - ценное лекарственное сырье, известны в китайской и тибетской медицине, а также в практике бурятских и монгольских лам под названием «хонг лен». На Востоке S. baicalensis применяется как укрепляющее, успокаивающее, жаропонижающее, смягчающее, отхаркивающее и противоглистное средство, его назначают при миокардите, остром ревматизме, эпилепсии, бессоннице, бронхитах, воспалении легких и других легочных заболеваниях $[4,8,13,14]$. В тибетской медицине растение является составной частью сборов для лечения печени [5]. В народной медицине России настойку из корня S. baicalensis применяют при усталости, нарушении работы сердечно-сосудистой системы, неврозах, предменструальном синдроме, климаксе.

В научной медицине $S$. baicalensis назначают в начальных стадиях гипертонической болезни, атеросклерозе, при бессоннице и неврозах, сочетающихся с повышенным артериальным давлением, нарушениями ритма сердца и воспалении сердечной мышцы (миокардите) [3, 4]. Препараты шлемника расширяют кровеносные сосуды, замедляют ритм сердечных сокращений, снижают артериальное давление, сочетающееся с атеросклерозом. Они устраняют головную боль и бессонницу, обладают успокаивающим действием, затормаживают функциональную активность нервной системы и предупреждают возникновение судорог [7, 9, 13].

Современные фармакологические исследования подтвердили, что экстракты и индивидуальные соединения, выделенные из растений рода Scutellaria L. - байкалин, байкалеин, вогонин - обладают противоопухолевым, гепатопротекторным, антиоксидантным, противовоспалительным, противосудорожным, антибактериальным и противовирусным действиями $[4,9,13,15-21]$. Вогонин, байкалеин и байкалин в эксперименте проявляют способность уменьшать содержание холестерина в клетках печени [10]. Сумма флавоноидов проявляет противовирусную активность в отношении вируса гриппа [9, 13]. Биологическая активность флавоноидов Scutellaria L. обусловила непрекращающийся интерес к этой теме и возрастающее число научных публикаций.

На территории Узбекистана произрастают 32 вида Scutellaria L. (по-узбекски кукамарон), некоторые из них используются в народной медицине для лечения эпилепсии, аллергии, невроза, гипертонии и других заболеваний [4, 22].

\section{Химический состав флавоноидов}

Анализ данных литературы о химическом составе флавоноидов растений рода Scutellaria свидетельствует о его разнообразии. Флавоноиды Scutellaria представлены флавонами, флаванонами, флавонолами, халконами, изофлавонами, бифлавонами и флаволигнанами $[4,8-11,13,23-25]$. К настоящему времени исследованы флавоноиды более 60 видов Scutellaria, из которых выделено и идентифицировано 301 вещество, в том числе: флавоны - 182, флаваноны - 70, флаванонолы - 9, халконы - 10, флавонолы - 13, изофлавоны - 5, флаволигнаны - 7, бифлавоноиды - 5 (табл. 1).

Самым распространенным и поэтому детально изученным является S. baicalensis. Разработаны методы количественного определения флавоноидов в его надземной части [26, 27]. К настоящему времени в различных органах S. baicalensis обнаружен 131 флавоноид, в том числе 96 производных флавона, 21 флаванона, 6 флавонола, 4 изофлавона, 3 флаванонола и один халкон.

По количеству обнаруженных флавоноидов далее следуют растения S. indica - 61, S. barbata - 51, S. amoena - 38, S. prastrata - 35, S. galericulata - 29, S. discolor - 27, а также S. ramosissima и S. supina, из которых выделено по 24 флавоноида. 
Таблица 1. Изученные виды Scutellaria и количество флавоноидов

\begin{tabular}{|c|c|c|c|c|c|c|c|c|c|c|}
\hline \multirow[b]{2}{*}{$\begin{array}{c}\text { № } \\
\Pi / \Pi\end{array}$} & \multirow[b]{2}{*}{ Виды } & \multicolumn{9}{|c|}{ Количество выделенных флавоноидов по группам } \\
\hline & & $\begin{array}{l}\overrightarrow{1} \\
\text { 号 } \\
\text { 愛 } \\
\text { 总 }\end{array}$ & 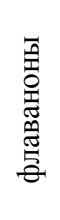 & 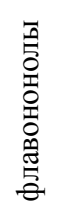 & 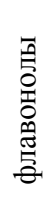 & 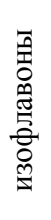 & 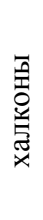 & 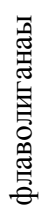 & 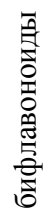 & 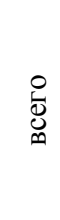 \\
\hline 1 & 2 & 3 & 4 & 5 & 6 & 7 & 8 & 9 & 10 & 11 \\
\hline S1 & S. adenostegia Briq. & 18 & 4 & - & 1 & - & - & - & - & 23 \\
\hline $\mathrm{S} 2$ & S. adsurgens M. Pop. & 14 & - & - & - & - & - & - & - & 14 \\
\hline $\mathrm{S} 3$ & S. alpina $\mathrm{L}$. & 20 & - & - & - & - & - & - & 1 & 21 \\
\hline S4 & S. altaica Rsch. ex. Sweet & 1 & - & - & - & - & - & - & - & 1 \\
\hline S5 & S. altissima $\mathrm{L}$. & 8 & 1 & - & - & - & - & - & - & 9 \\
\hline S6 & S. amabilis H.Hara & 12 & 7 & - & - & - & - & - & 2 & 21 \\
\hline S7 & S. amoena C. H. Wright. & 21 & 8 & 6 & 2 & - & 1 & - & - & 38 \\
\hline $\mathrm{S} 8$ & S. araxensis Grossh. & 5 & - & - & - & - & - & - & & 5 \\
\hline S9 & S. baicalensis Georgi. & 96 & 21 & 3 & 6 & 4 & 1 & - & - & 131 \\
\hline $\mathrm{S} 10$ & S. barbata D.Don & 35 & 15 & - & 1 & - & - & - & - & 51 \\
\hline S11 & S. caucasica A.Ham. & 16 & - & - & - & - & - & - & - & 16 \\
\hline $\mathrm{S} 12$ & S. columnae All. & 2 & - & - & - & - & - & - & - & 2 \\
\hline $\mathrm{S} 13$ & S. comosa Juz. & 15 & 2 & & 1 & - & - & - & - & 18 \\
\hline S14 & S. discolor Colebr. & 19 & 6 & - & - & - & 1 & - & 1 & 27 \\
\hline $\mathrm{S} 15$ & S. galericulata L. & 23 & 6 & - & - & - & - & - & - & 29 \\
\hline $\mathrm{S} 16$ & S. glabrata Vved. & 7 & - & - & - & - & - & - & - & 7 \\
\hline S17 & S. granulosa Juz. & 2 & - & - & - & - & - & - & - & 2 \\
\hline S18 & S. grossa Wall. & 16 & 1 & - & - & - & - & - & - & 17 \\
\hline S19 & S. guttata Nevski ex Juz. & 9 & - & - & - & - & - & - & - & 9 \\
\hline $\mathrm{S} 20$ & S. haematochlora Juz. & 3 & 1 & - & - & - & - & - & - & 4 \\
\hline $\mathrm{S} 21$ & S. havanensis Jacq. & 1 & & & & & & & & 1 \\
\hline S22 & S. holosericea Gontsch ex Juz & 4 & - & - & 1 & - & - & - & - & 5 \\
\hline $\mathrm{S} 23$ & S.hypericifolia H.Lév. & 3 & - & - & 1 & - & - & - & - & 4 \\
\hline $\mathrm{S} 24$ & S. immaculata Nevski & 18 & 3 & - & 1 & - & - & - & - & 22 \\
\hline $\mathrm{S} 25$ & S. incona Spreng. & 1 & - & - & - & - & - & - & - & 1 \\
\hline S26 & S. indica $\mathrm{L}$. & 29 & 27 & - & - & - & 5 & - & - & 61 \\
\hline $\mathrm{S} 27$ & S. iskanderi Juz. & 9 & - & - & - & - & - & - & - & 9 \\
\hline S28 & S. karjaginii Grossh & 4 & - & - & - & - & - & - & - & 4 \\
\hline $\mathrm{S} 29$ & S. lateriflora $\mathrm{L}$. & 4 & - & - & - & - & - & - & - & 4 \\
\hline $\mathrm{S} 30$ & S. likiangensis Diels & 2 & - & - & - & - & - & - & - & 2 \\
\hline $\mathrm{S} 31$ & S. linearis Benth. & 5 & - & 1 & - & - & - & - & 1 & 7 \\
\hline S32 & S. litwinowii Bornm. et. Sint. & 9 & - & - & - & - & - & - & - & 9 \\
\hline S33 & S. nepetoides M. Pop. & 5 & - & - & - & - & - & - & - & 5 \\
\hline $\mathrm{S} 34$ & S. ocellata Juz. & 8 & - & & 1 & - & - & - & - & 9 \\
\hline S35 & S. oreophila Grossh. & 5 & - & - & - & - & - & - & - & 5 \\
\hline S36 & S. orientalis L. & 11 & - & - & - & - & - & - & - & 11 \\
\hline S37 & S. ovata Hill. & 6 & - & - & - & - & - & - & - & 6 \\
\hline S38 & S. oxystegia Juz. & 2 & 1 & - & - & - & - & - & - & 3 \\
\hline S39 & S. pekinensis Maxim. & 16 & - & 1 & 1 & - & 1 & - & - & 19 \\
\hline S40 & $\begin{array}{l}\text { S. pekinensis var. ussuriensis(Regel) } \\
\text { Hand.-Mazz. }\end{array}$ & 4 & - & - & - & - & - & - & - & 4 \\
\hline $\mathrm{S} 41$ & S. phyllostachya Juz. & 14 & 4 & - & - & - & - & - & - & 18 \\
\hline $\mathrm{S} 42$ & S. pinnatifida A.Ham. & 2 & - & - & - & - & - & - & - & 2 \\
\hline $\mathrm{S} 43$ & S. platystegia Juz. & 1 & - & - & - & - & - & - & - & 1 \\
\hline $\mathrm{S} 44$ & S. pontica C. Koch. & 4 & - & - & - & - & - & - & - & 4 \\
\hline $\mathrm{S} 45$ & S. prilipkoana Grossh. & 1 & - & - & - & - & - & - & - & 1 \\
\hline $\mathrm{S} 46$ & S. prostrata Jacq. et Benth. & 26 & - & - & - & - & - & 8 & 1 & 35 \\
\hline S47 & S. przewalskii Juz. & 18 & - & - & - & - & - & - & - & 18 \\
\hline $\mathrm{S} 48$ & S. pycnoclada Juz. & 13 & - & - & - & - & - & - & - & 13 \\
\hline S49 & S. ramosissima M. Pop. & 17 & 4 & - & 3 & - & - & - & - & 24 \\
\hline S50 & $\begin{array}{l}\text { S. regeliana var. ikonnikovii (Juz.) } \\
\text { C.Y.Wu \& H.W.Li. }\end{array}$ & 8 & - & - & - & - & - & - & - & 8 \\
\hline
\end{tabular}


Окончание таблищь 1

\begin{tabular}{c|l|c|c|c|c|c|c|c|c|c}
\hline \multicolumn{1}{|c|}{2} & 3 & 4 & 5 & 6 & 7 & 8 & 9 & 10 & 11 \\
\hline S51 & \multicolumn{1}{|c|}{ S.repens Buch.-Ham. ex D.Don } & 6 & 1 & - & - & - & - & - & - & 7 \\
S52 & S. rehderiana Diels. & 7 & - & - & - & - & - & - & - & 7 \\
S53 & S. scandens D. Don. & 8 & 9 & - & - & - & - & - & - & 17 \\
S54 & S. scordiifolia Fisch. ex Schrank & 20 & 3 & - & - & 1 & - & - & - & 24 \\
S55 & S. seleriana Loes & 1 & - & - & - & - & - & - & - & 1 \\
S56 & S. sevanensis Sosn. & 17 & 2 & - & - & - & - & - & - & 19 \\
S57 & S. squarrosa Nevsk $i$ & 6 & - & - & - & - & - & - & - & 6 \\
S58 & S. strigillosa Hemsl & 12 & 4 & - & - & - & 1 & - & - & 17 \\
S59 & S. supina L. & 22 & 2 & - & - & - & - & - & - & 24 \\
S60 & S. schachristanica Zuz. & 15 & - & - & 2 & - & - & - & - & 17 \\
S61 & S. tenax W. W. Smith. & 4 & - & 1 & 1 & - & - & - & - & 6 \\
S62 & S. tournefortii Benth. & 4 & - & - & - & - & - & - & - & 4 \\
S63 & S. viscidula Bunge & 15 & 2 & 2 & 1 & - & - & - & - & 20 \\
\hline
\end{tabular}

Наличие флавоноидов в растениях S. albida L., Scutellaria orientalis subsp. karatschaica (Kharadze) Menitsky, S. mesostegia Juz., S. grindiflora Sims., S. oligodonta Juz., S. paulsenii Briq. и S. sedelmeyeria Juz. определено на основании качественных реакций и данных хроматографического анализа [4, 25, 28].

Флавоны по качественному составу доминируют среди флавоноидов растений рода Scutellaria. Разнообразие флавонов обусловлено природой, количеством и взаимным расположением замещающих групп (табл. 2).

По характеру замещения основного скелета все флавоны растений рода Scutellaria можно разбить на 5 групп: ди-, три-, тетра-, пента- и гексазамещенные. Дизамещенные флавоны представлены хризином (5,7-замещенным), его метиловыми эфирами и $O$ - и $C$-гликозидами (всего 14 соединений). Из S. baicalensis выделены 6-гидроксифлавон и 8-метокси-5-O-глюкозилфлавон, не содержащие заместителей в положении $C$-7 [8]. Тризамещенные флавоны - вторая по распространению группа, делится на четыре типа: байкалеина $(5,6,7)$, норвогонина $(5,7,8), 2^{\prime}$-оксихризина $\left(5,7,2^{\prime}\right)$, и апигенина $\left(5,7,4^{\prime}\right)$. Природные производные вышеуказанных флавоноидов представлены в основном их метиловыми эфирами и гликозидами.

Группа тетразамещенных флавонов самая многочисленная (35 соединений) и представлена $5,6,7,8$-, 5,6,7,2'-, 5,7,8,2'-, 5,6,7,4'-, 5,7,8,4'-, 5,7,8,2'-, 5,7,3',4'-, 5,7,2',6'-тетразамещенными флавонами. Помимо указанных типов, в S. baicalensis обнаружены флавоны с необычным расположением гидроксильных групп $5,7,2^{\prime}, 3^{\prime}$ и $5,7,2^{\prime}, 5^{\prime}$.

Пента- и гексазамещенные флавоны имеют различные типы гидроксилирования. Многие из них содержат кислородные (гидроксильные, метоксильные и $O$-гликозидные) функции в положениях 2' и/или 6'. Эти соединения относятся к группе редких производных флавона и, по мнению Ø.M. Andersen и K.R. Markham, являются характеристическими хемотаксономическими признаками на уровне как рода Scutellaria L., так и семейства Lamiaceae в целом [29].

Для растений рода Scutellaria наиболее характерны дизамещенные производные флавона - хризин (обнаружен в 36 видах), тризамещённые флавоны - вогонин (36), ороксилин (27), байкалеин (33), апигенин (29), норвогонин (18), и тетразамещенные флавоны - скутеллареин (23), лютеолин (19), гиспидулин (13), а также их гликозиды. Углеводная часть $O$-гликозидов флавонов представлена моносахаридами $D$ глюкуро- новой кислотой (38 соединений), $D$-глюкозой (29), $D$-галактуроновой кислотой (4) и $L$-рамнозой (1), а также дисахаридами рутинозой (3), неогесперидозой (3) и 6-O- $\alpha$ - $L$-арабинопиранозил- $\beta$-Dглюкопиранозой (1). Обнаружены также метиловые, этиловые и синапоильные эфиры глюкуронидов (7) и 2 диглюкуронида. $C$-Гликозиды представлены 5 гликозидами хризина - двумя монозидами (6- $C$ - и 8- $C$ глюкозиды), тремя дигликозидами (6- $C$-глюкозид-8- $C$-арабинозидом, 6- $C$-арабинозидом-8- $C$-глюкозидом и 6,8-ди- $C$-глюкозидом) и двумя гликозидами апигенина.

Наличие уронидов является характерной особенностью флавоноидов Scutellaria L. B pacтениях этого рода наиболее часто встречаются 7-O-D-глюкурониды байкалеина (33 вида), скутеллареина (29), вогонина (26), хризина (24), ороксилина А (17), апигенина (17) и лютеолина (12).

И.И. Чемесова предлагает классифицировать флавоноиды растений рода Scutellaria L. по типу замещения в кольце В, условно разделив их на 5 групп: флавоноиды с незамещенным кольцом В, флавоноиды с замещением в положении 2', флавоноиды с замещением в положениях 2',3'; 2', 5' и 2',6', флавоноиды с замещением в положениях 2',3',6' и 2',5',6', флавоноиды с обычным замещением в положениях 4' и 3',4' [10]. 
Для изученных видов растений рода Scutellaria L. наиболее характерны флавоноиды, незамещенные в кольце В (хризин, байкалеин, норвогонин, вогонин, ороксилин А и их гликозиды и $O$-метиловые эфиры), монозамещенные в положении 2' (2'-гидроксихризин, 2'-гидроксибайкалеин, тенаксин, 2'-гидроксинорвогонин, скутевулин, скуллкапфлавон), монозамещенные в положении 4' (апигенин, акацетин, скутеллареин, изоскутеллареин, гиспидулин, динатин, изодинатин, пектолинаригенин, сальвигенин и их гликозиды, метиловые эфиры), дизамещенные в положениях 2',5' (5,7,2',5'-тетрагидроксифлавон и его 7-O-глюкуронид, 5,7,2',5'-тетраметоксифлавон, 5,2',5'-тригидрокси-6,7-диметоксифлавон, флавон, редерианин, 5,2',5'-тригидрокси-6,7,8-триметоксифлавон), дизамещенные в положениях 2',6' (5,7,2',6'-тетрагидроксифлавон, висцидулин, ривулярин, алтизин), дизамещенные в положениях 2',3' (5,7,2',3'-тетрагидроксифлавон, 5,7,2',3'тетраметоксифлавон, 5,2'-дигидрокси-6,7,8,3'-тетраметоксифлавон, 5,7-дигидрокси-6,8,2',3'-тетраметоксифлавон), дизамещенные в положениях 3',4' (лютеолин, 5-гидрокси-7,3',4'-триметоксифлавон, 6- и 8гидроксилютеолины, их гликозиды и метиловые эфиры, цирсилинеол), а также тризамещенные в кольце В флавоноиды (висцидулин III и его глюкозид, 5-гидрокси-7,8,2',5',6'-пентаметоксифлавон, 5,7,3',6'-тетрагидрокси-6,2'-диметоксифлавон, 5,2',5'-тригидрокси-7,8,6'-триметоксифлавон, 5,7,3',6'-тетрагидрокси-6,8,2'триметоксифлавон и др.).

Из S. baicalensis выделено 96 производных флавона.

Таблица 2. Флавоны и их гликозиды рода Scutellaria L.

\begin{tabular}{|c|c|c|}
\hline $\begin{array}{l}\text { № } \\
\text { П/П }\end{array}$ & Название флавоноида & Вид Scutellaria (номер согласно таблице 1), ссылка \\
\hline 1 & 2 & 3 \\
\hline 1 & 6-гидроксифлавон & S9 [8] \\
\hline 2 & 5,7-дигидроксифлавон (хризин) & $\begin{array}{c}\mathbf{S 1}[54], \mathbf{S 2}[4,10], \mathbf{S 3}[30], \mathbf{S 7}[31], \mathbf{S 8}[4,25], \mathbf{S 9}[23,25], \mathbf{S 1 1} \\
{[28,46], \mathbf{S 1 3}[32], \mathbf{S 1 4}[25,33], \mathbf{S 1 5}[25,34-36], \mathbf{S 1 6}[37], \mathbf{S 1 7}} \\
{[4,10], \mathbf{S 1 8}[38], \mathbf{S 1 9}[39], \mathbf{S 2 2}[40], \mathbf{S 2 4}[42], \mathbf{S 2 6}[25,41,104],} \\
\mathbf{S 2 8}[10], \mathbf{S 3 1}[43], \mathbf{S 3 5}[4,10], \mathbf{S 3 6}[4,44], \mathbf{S 3 7}[25], \mathbf{S 3 8}[28], \\
\mathbf{S 4 1}[45], \mathbf{S 4 6}[50], \mathbf{S 4 7}[10], \mathbf{S 4 8}[47], \mathbf{S 4 9}[24], \mathbf{S 5 3}[76], \mathbf{S 5 4} \\
{[10,11,95], \mathbf{S 5 6}[25], \mathbf{S 5 7}[28,48], \mathbf{S 5 8}[25,49], \mathbf{S 5 9}[10,47],} \\
\mathbf{S 6 0}[52], \mathbf{S 6 3}[8,53]\end{array}$ \\
\hline 3 & Хризин-7-O-Glcp ${ }^{*}$ & $\mathbf{S 9}[23,25], \mathbf{S 2 2}[40] \mathbf{S 3 6}[4,25]$ \\
\hline 4 & Хризин-7-O-GlcAp & $\begin{array}{c}\text { S1 [55], S2 [4, 25], S3 [30], S7 [8, 31], S9 [23, 25], S11 [28, } \\
46], \mathbf{S 1 3}[56], \mathbf{S 1 4}[25,33], \mathbf{S 1 5}[25,34-36], \mathbf{S 1 6}[37], \mathbf{S 1 7}[4], \\
\text { S18 }[8,38], \mathbf{S 2 4}[24,59], \mathbf{S 2 6}[41,104], \mathbf{S 3 6}[4], \mathbf{S 3 9}[60], \mathbf{S 4 6} \\
{[8,50], \mathbf{S 4 8}[25], \mathbf{S 4 9}[24,61], \mathbf{S 5 0}[28,57,58], \mathbf{S 5 3}[76], \mathbf{S 5 4}} \\
{[11,25,95], \mathbf{S 5 9}[25], \mathbf{S 6 0}[62] .}\end{array}$ \\
\hline 5 & Хризин-7-O-(6"-OMe)GlcAp & S13 [32], S19 [39], S41 [63], S60 [62] \\
\hline 6 & Хризин-7-O-GalAp & S60 [64] \\
\hline 7 & Хризин-7-O-(6"-Arap)-Glcp & S60 [65] \\
\hline 8 & Хризин-6-C-Glcp & $\mathbf{S 9}[23,25]$ \\
\hline 9 & Хризин-8-C-Glcp & $\mathbf{S 7}[8], \mathbf{S 9}[23,25]$ \\
\hline 10 & Хризин-6-C-Glcp-8-C-Arap & $\mathbf{S 7}$ [8], S9 [23], S39 [60] \\
\hline 11 & Хризин-6-C-Arap-8-C-Glcp & S9 [23], S39 [60], S49 [24] \\
\hline 12 & Хризин-6,8-ди-C-Glcp & S15 $[51]$ \\
\hline 13 & 5-Гидрокси-7-метоксифлавон & S22 [40] \\
\hline 14 & 5-Гидрокси-8-метоксифлавон-5-O-Glcp & S9 [8] \\
\hline 15 & 7-Гидрокси-5-метоксифлавон-7-O-Glcp & S15 [51] \\
\hline 16 & 7-Гидрокси-5-метоксифлавон-7-O-GlcAp & S15 [51] \\
\hline 17 & 5,6,7-Тригидроксифлавон (байкалеин) & $\begin{array}{c}\text { S1 [54], S2 [47], S3 [30], S5 [4], S7 [8, 31], S8 [4], S9 [4,8,99], } \\
\text { S10 }[8,25,66], \mathbf{S 1 1}[46,28], \mathbf{S 1 3}[56], \mathbf{S 1 5}[25,34-36], \mathbf{S 1 8} \\
{[38], \mathbf{S} 23[8], \mathbf{S 2 4}[24], \mathbf{S 2 7}[72], \mathbf{S 2 9}[8,67,68], \mathbf{S 3 2}[4], \mathbf{S 3 5}} \\
{[4], \mathbf{S 3 6}[4,44], \mathbf{S 3 9}[69], \mathbf{S 4 1}[25], \mathbf{S 4 6}[50], \mathbf{S 4 8}[25], \mathbf{S 4 9}} \\
{[24], \mathbf{S 5 2}[25], \mathbf{S 5 3}[76], \mathbf{S 5 4}[4,11], \mathbf{S 5 6}[25], \mathbf{S 5 7}[28,48],} \\
\mathbf{S 5 8}[70], \mathbf{S 5 9}[4,25], \mathbf{S 6 1}[10], \mathbf{S 6 3} 8,53]\end{array}$ \\
\hline 18 & Байкалеин-7-O-Glcp & $\mathbf{S 7}[8,31], S 9$ [4, 8, 23], S16 [71], S24 [59], S39 [69], S41 [63] \\
\hline 19 & Байкалеин-7-O-GlcAp (байкалин) & $\begin{array}{c}\mathbf{S 1}[25], \mathbf{S 2}[47], \mathbf{S 3}[30], \mathbf{S 5}[4], \mathbf{S 7}[8,31], \mathbf{S 8}[4], \mathbf{S 9}[8,23, \\
99] \mathbf{S 1 0}[8,66,74], \mathbf{S 1 1}[46,28], \mathbf{S 1 2}[25], \mathbf{S 1 3}[56], \mathbf{S 1 5}[25, \\
34-36], \mathbf{S 1 8}[38], \mathbf{S 2 4}[24], \mathbf{S 2 6}[104], \mathbf{S 2 7}[72], \mathbf{S 2 9}[8,68] \mathbf{S 3 2} \\
{[4], \mathbf{S 3 4}[73], \mathbf{S 3 5}[4], \mathbf{S 3 6}[4], \mathbf{S 3 9}[69], \mathbf{S 4 6}[50,108], \mathbf{S 4 7}[4],} \\
\mathbf{S 4 8}[47], \mathbf{S 4 9}[24], \mathbf{S 5 0}[28,57,58], \mathbf{S 5 3}[76], \mathbf{S 5 4}[4,11], \mathbf{S 5 7} \\
{[28,48], \mathbf{S 5 8}[70], \mathbf{S 5 9}[4,47], \mathbf{S 6 3}[8]}\end{array}$ \\
\hline
\end{tabular}


Продолжение таблиџь 2

\begin{tabular}{c|l|c}
\hline \multicolumn{1}{|c|}{2} & \multicolumn{1}{|c}{} \\
\hline 20 & \multicolumn{1}{|c}{ Байкалеин-7-O-(6"-OEt)GlcAp} & $\mathbf{S 9}[98]$ \\
21 & Байкалеин-6-O-GlcAp & $\mathbf{S 9}[23,25], \mathbf{S 1 8}[8,38]$ \\
22 & Байкалеин-7-O-Rhap (галерозид) & $\mathbf{S 1 5}[8,25]$ \\
23 & Байкалеин-6,7-ди-O-GlcAp & $\mathbf{S 9}[23,25]$ \\
24 & Байкалеин-6-O-GlcAp-7-O-SO${ }_{3}^{-}$ & $\mathbf{S 9}[23,25]$ \\
25 & 5,6-дигидрокси-7-метоксифлавон & $\mathbf{S 9}[23,25]$ \\
26 & 5-гидрокси-6,7-диметоксифлавон & $\mathbf{S 9}[23]$ \\
27 & 7-гидрокси-5,6-диметоксифлавон-7-O-Glcp & $\mathbf{S 3 7}[8,25]$ \\
& (оватин) &
\end{tabular}

5,7,8-тригидроксифлавон (норвогонин)

Норвогонин-7-O-Glcp Норвогонин-8-O-Glcp Норвогонин-7-O-GlcAp (норвогонозид)

Норвогонин-8-O-GlcAp

Норвогонин-8-O-(6"-OMe)GlcAp (скутелларинозид F)

5,7,8-тригидроксифлавон-7-O-GalAp (непетозид А)

5,8-дигидрокси-7-метоксифлавон

5-гидрокси-7,8-диметоксифлавон

7-гидрокси-5,8-диметоксифлавон

7-гидрокси-5,8-диметоксифлавон-7-O-GlcAp

7-гидрокси-5,8-диметоксифлавон-7-O-Glcp (иммакулозид)

5,7-дигидрокси-8-метоксифлавон (вогонин)

Вогонин-7-O-GlcAp (вогонозид)

Вогонин-7-O-(6"-OEt)GlcAp

Вогонин-7-O-Glcp

Вогонин-5-O-Glcp

5,7-дигидрокси-6-метоксифлавон (ороксилин А)

Ороксилин А-7-O-Glcp

Ороксилин А-7-O-GlcAp

(ороксилозид)

Ороксилин А-7- O-(6"-OMe)GlcAp

5,7,2'-тригидроксифлавон (2'-гидроксихризин)

5,7,2'-тригидроксифлавон 2'-O-Glcp

5,7-дигидрокси-2'-метоксифлавон

(2'-метокси- хризин)

7,2'-дигидрокси-5-метоксифлавон

5,7,2'-тригидроксифлавон-7-O-Glcp

5,7,2'-тригидроксифлавон-7-O-GlcAp

5,7-дигидрокси-2'-метоксифлавон-7-O-GlcAp
S1 [55], S3 [30], S7 [8, 10], S9 [8, 23, 25, 99], S13 [56], S14 [25, 33], S15 [25], S18 [38], S24 [24], S39 [69], S40 [25], S41 [45], S46 [50], S49 [24,75], S53 [76], S58 [8, 25, 49], S59 [25], $\mathbf{S 6 3}[8,53]$

S9 [23 ,25], S14 [25], S24 [25, 59], S41 [63] S50 [25]

S15 [25], S18 [8,38], S24 [24], S33 [73], S46 [8,50], S49 [24], $\mathbf{S 5 0}[28,57,58], \mathbf{S 5 4}[11]$

S14 [33, 77], S26 [105], S33 [78], S50 [28, 58] S26 [105]

$\mathbf{S 3 3}[73,79]$

S9 [23, 25], S34 [96], S58 [25, 70]

S9 [8, 23, 25, 99], S10 [8, 25], S34 [96], S40 [4]

S10 [25], S14 [10, 77], S40 [10]

S10 $[8,74]$

S24 $[25,59]$

S1 [55], S3 [30], S5 [4], S7 [8], S6 [80], S9 [8, 23, 25, 71, 98, 99], S10 [8, 66, 74, 100], S11 [25, 46], S13 [32], S14 [33], S15 [25, 34-36], S16 [37], S18 [38], S19 [39], S21 [102], S24 [24, 42], S26 [25, 81, 82, 104], S27 [72], S31 [43], S29 [8, 68, 83] S34 [73], S36 [4, 10, 44], S42 [106], S46 [50], S39 [69], S41 [45], S49 [24, 75], S52 [8], S53 [76], S54 [4], S56 [25], S57 [48, 28], S58 [70], S59 [47], S60 [62], S61 [10], S63 [8, 53]. S1 [55], S3 [30], S5 [4], S7 [8], S9 [8, 23, 25, 98], S10 [74], S11 [25, 46], S13 [56], S14 [8, 33], S15 [34-36], S18 [38], S24 [24, 59], S26 [25, 81, 82, 104], S27 [72], S31 [43], S34 [73], S36 [4], S39 [69], S41 [63], S46 [50, 108], S49 [24], S53 [76], $\mathbf{S 5 4}[4,11], \mathbf{S 5 8}$ [70], S59 [47], S63 [8, 53].

$$
\begin{gathered}
\text { S9 [98] } \\
\text { S24 [42] } \\
\text { S9 }[8,23,25]
\end{gathered}
$$

S1 [55], S3 [30], S5 [4], S7 [8,31], S9 [8, 23, 25, 71, 98, 99], S13 [84], S15 [25, 34-36], S18 [38], S19 [39], S23 [8], S27 [72], S32 [4], S34 [73], S38 [28, 85], S46 [50], S49 [75], S52 [8], S53 [76], S54 [4, 10], S55 [8, 24], S56 [25], S57 [48, 28],

S58 [70], S59 [47], S60 [62], S61 [10], S63 [8, 53] S24 [24], S37 [8,25], S49 [24], S59 [4,25]

S1 [55], S3 [30], S5 [4], S7 [31], S9 [25], S13 [32], S15 [25, 34-36], S18 [38], S24 [59], S27 [72], S32 [4], S41 [63], S46

[50], S49 [24], S54 [4, 64], S57 [28, 48], S59 [47] S7 [8, 31], S9 [98]

S2 [25], S3 [10,30], S6 [80], S9 [8, 23,25], S46 [50], S48 [47], S56 [25], S58 [49], S62 [4,10] S6 [80]

S1 [54], S15 [25], S17 [4, 10, 95], S36 [44], S41 [86], S46 [8, 50], S54 [4, 10], S56 [25], S58 [70] S39 [69] S49 [87]

S13 [56], S30 [8], S48 [47], S50 [28, 57, 58], S62 [4] S17 [4, 25], S46 [8, 48], S54 [4] 
Продолжение таблищьь 2

\begin{tabular}{|c|c|c|}
\hline 1 & 2 & 3 \\
\hline 56 & $\begin{array}{l}\text { 5,7,4'-тригидроксифлавон } \\
\text { (апигенин) }\end{array}$ & $\begin{array}{c}\text { S1 [54], S2 [4], S3 [30], S9 [23, 25, 100], S10 [8, 10, 100, 103], } \\
\text { S11 [28, 46], S13 [32], S14 [33], S15 [25, 34-36], S19 [39], } \\
\text { S22 [40], S24 [42], S26 [25, 41, 82, 104], S27 [72], S28 [4, 10], } \\
\text { S31 [43], S34 [73], S36 [10, 44], S37 [10], S39 [60], S44 [88], } \\
\text { S46 [8], S47 [4, 10], S48 [47], S54 [10, 11], S56 [25], S59 [47] } \\
\text { S58 [8, 49], S60 [52] }\end{array}$ \\
\hline 57 & Апигенин-7-O-Glcp (космосиин) & $\begin{array}{c}\text { S1 [47], S2 [47], S10 [103], S13 [32], S15 [25, 35, 36], S19 } \\
{[39], \mathbf{S 2 4}[42,59], \mathbf{S 4 1}[63], \mathbf{S 4 3}[107], \mathbf{S 4 4}[88], \mathbf{S 4 7}[25], \mathbf{S 5 4}} \\
{[11], \mathbf{S 5 9}[4,8], \mathbf{S 6 0}[52]}\end{array}$ \\
\hline 58 & Апигенин-7-O-GlcAp & $\begin{array}{c}\mathbf{S 1} \text { [47], S2 [4], S3 [8, 30], S9 [23], S10 [103], S11 [28], S15 } \\
{[25,34-36], \mathbf{S 2 6}[41,81,104], \mathbf{S 2 7}[72], \mathbf{S 3 3}[73,78], \mathbf{S 4 1}[63],} \\
\mathbf{S 4 6}[8], \mathbf{S 4 7}[25], \mathbf{S 4 8}[47], \mathbf{S 5 4}[4,11], \mathbf{S 5 9}[47], \mathbf{S 6 0}[64]\end{array}$ \\
\hline 59 & Апигенин-7-O-GalAp & S60 [64] \\
\hline 60 & Апигенин-6-C-Glcp (изовитексин) & S44 [88] \\
\hline 61 & Апигенин-6,8-ди-C-Glcp & S59 [25] \\
\hline 62 & Апигенин-7-O-(6"-Rhap)-Glcp (роифолин) & S11 $[46,28]$ \\
\hline 63 & 5,7-дигидрокси-4'-метоксифлавон (акацетин) & S11 [28], S46 [8], S56 [25] \\
\hline 64 & Акацетин-7-O-Glcp (тилианин) & S11 $[8,28], \mathbf{S 4 4}[88]$ \\
\hline 65 & Акацетин-7-O-(6"-Rhap)-Glcp (линарин) & $\mathbf{S 1 1}[8,28]$ \\
\hline 66 & Акацетин-7-O-(6"-GlcAp)-GlcAp & S10 [101] \\
\hline 67 & 5,7,8-тригидрокси-6-метоксифлавон & S9 [99] \\
\hline 68 & 5,7-дигидрокси-6,8-диметоксифлавон & S9 [23], S51 [24, 25], S56 [25] \\
\hline 69 & 5,7-дигидрокси-6,8-диметоксифлавон-7-O-GlcAp & S51 [25] \\
\hline 70 & 5,8-дигидрокси-6,7-диметоксифлавон & S9 $[8,23,25]$ \\
\hline 71 & 5,6-дигидрокси-7,8-диметоксифлавон & $\mathbf{S 4 9}[75]$ \\
\hline 72 & 5-гидрокси-6,7,8-триметоксифлавон (альнетин) & S9 [99] \\
\hline 73 & $\begin{array}{l}\text { 5,6,7,2'-тетрагидроксифлавон } \\
\text { (2'-гидроксибай- калеин) }\end{array}$ & S9 [23], S56 [25] \\
\hline 74 & $\begin{array}{l}\text { 5,6,7,2'-Тетрагидроксифлавон-7-O-GlcAp } \\
\text { (иконникозид I) }\end{array}$ & $\mathbf{S 3 0}[8], \mathbf{S 5 0}[28,57,58]$ \\
\hline 75 & 5,7,2'-тригидрокси-6-метоксифлавон (тенаксин II) & $\mathbf{S 7}[8,31], \mathbf{S 9}[8,23,25], \mathbf{S 6 3}[8,25]$ \\
\hline 76 & Тенаксин II-7-O-Glcp & $\mathbf{S 7}[8,31]$ \\
\hline 77 & Тенаксин II-7-O-GlcAp & $\mathbf{S 7}[8,31], \mathbf{S 9}[23,25]$ \\
\hline 78 & Тенаксин II-7-O-(6"-OMe $) G l c A p$ & $\mathbf{S 7}[8,31]$ \\
\hline 79 & 5,7,8,2'-тетрагидроксифлавон & $\mathbf{S 1 4}$ [10], S32 [25], S59 [25] \\
\hline 80 & 5,7,8,2'-тетрагидроксифлавон-7-O-Glcp & $\mathbf{S 1 0}[8]$ \\
\hline 81 & 5,7,8,2'-тетрагидроксифлавон-7-O-GlcAp & $\mathbf{S 1 0}[8,74,103], \mathbf{S 2 6}[104]$ \\
\hline 82 & 5,8,2'-тригидрокси-7-метоксифлавон & S9 $[8,10,23,25]$ \\
\hline 83 & $\begin{array}{l}\text { 5, 7, 2'-тригидрокси-8-метоксифлавон } \\
\text { (скутевулин) }\end{array}$ & $\begin{array}{c}\mathbf{S 3}[10,30], \mathbf{S 6}[80], \mathbf{S 9}[8,23,25,99], \mathbf{S 1 0}[8,10], \mathbf{S} 14[10, \\
25], \mathbf{S 2 6}[8,82], \mathbf{S 4 6}[50]\end{array}$ \\
\hline 84 & 5,7,2'-тригидрокси-8-метоксифлавон 7-O-Glcp & S6 [80] \\
\hline 85 & 5,7,2'-тригидрокси-8-метоксифлавон 2'-O-Glcp & S6 [80] \\
\hline 86 & 5,7,2'-тригидрокси-8- метоксифлавон-7-O-GlcAp & S10 [103], S26 [104], S46 [8, 50] \\
\hline 87 & 5,7-дигидрокси-8,2'-диметоксифлавон & $\mathbf{S 6}[80], \mathbf{S 1 0}[8,10], \mathbf{S 1 4}[8,25,33], \mathbf{S 2 6}[25,81,82,104], \mathbf{S 5 8}$ [70] \\
\hline 88 & 5,7-дигидрокси-8,2'-диметоксифлавон-7-O-Glcp & S6 [80], S10 [25] \\
\hline 89 & 5,7-дигидрокси-8,2'-диметоксифлавон 7-O-GlcAp & $\mathbf{S 6}[80], \mathbf{S 2 6}[8,41,104]$ \\
\hline 90 & $\begin{array}{l}\text { 5,2'-дигидрокси-7,8-диметоксифлавон } \\
\text { (скуллкапфлавон I) }\end{array}$ & $\mathbf{S 3}$ [25], S9 [8, 23,25], S10 [25], S16 [37], S39 [69], S46 [50] \\
\hline 91 & 7-гидрокси-5,8,2'-триметоксифлавон & S14 $[8,10,77]$ \\
\hline 92 & 5-гидрокси-7,8,2'-триметоксифлавон & $\mathbf{S 9}[8,10,25], \mathbf{S 1 8}[38]$ \\
\hline 93 & 5,2'-дигидрокси-6,8-диметоксифлавон & S9 $[10,25]$ \\
\hline 94 & 2'-гидрокси-5,7,8-триметоксифлавон & S9 $[10,23]$ \\
\hline 95 & $\begin{array}{l}\text { 5,6,7,4'-тетрагидроксифлавон } \\
\text { (скутеллареин) }\end{array}$ & $\begin{array}{c}\text { S1 [25], S2 [4], S3 [30], S5 [25], S9 [8, 23, 25], S10 [8, 10, 100, } \\
103], \mathbf{S 1 1}[4,46], \mathbf{S 1 3}[84], \mathbf{S 1 5}[10,34], \mathbf{S 1 8}[38], \mathbf{S 1 9}[39], \\
\mathbf{S 2 4}[42,59], \mathbf{S 2 6}[25,41,104], \mathbf{S 3 2}[4], \mathbf{S 3 6}[4], \mathbf{S 4 7}[4], \mathbf{S 4 8} \\
{[25], \mathbf{S 5 2}[8], \mathbf{S 5 4}[4,10], \mathbf{S 5 6}[25], \mathbf{S 5 9}[25], \mathbf{S 6 0}[52], \mathbf{S 6 2}} \\
{[25], \mathbf{S 6 3}[8]}\end{array}$ \\
\hline 96 & Скутеллареин-7-O-Glcp & $\begin{array}{c}\mathbf{S 1 0}[103], \mathbf{S 1 9}[39], \mathbf{S 2 4}[25,59], \mathbf{S 2 6}[8,41], \mathbf{S 4 1}[63], \mathbf{S 4 7} \\
{[4,25], \mathbf{S 6 0}[52]}\end{array}$ \\
\hline
\end{tabular}


Продолжение таблищьь 2

\begin{tabular}{|c|c|}
\hline 1 & 2 \\
\hline 97 & $\begin{array}{l}\text { Скутеллареин-7-O-GlcAp } \\
\text { (скутелларин) }\end{array}$ \\
\hline 98 & Скутеллареин-7-O-(6"-OSin)-GlcAp \\
\hline 99 & Скутеллареин-7-O-(2"-Rhap)-Glcp \\
\hline 100 & $\begin{array}{l}\text { 5,7,4'-тригидрокси-6-метоксифлавон } \\
\text { (гиспидулин) }\end{array}$ \\
\hline 101 & Гиспидулин-7-O-Glcp \\
\hline 102 & Гиспидулин-7- O-GlcAp (гиспидулозид) \\
\hline 103 & Гиспидулин-7-O-(2"-Rhap)-Glcp \\
\hline 104 & 5,6,7,-тригидрокси-4'-метоксифлавон (динатин) \\
\hline 105 & Динатин-7-O-Glcp \\
\hline 106 & Динатин-7-O-GlcAp \\
\hline 107 & Динатин-7-O-(2"-Rhap)-Glcp \\
\hline 108 & $\begin{array}{l}\text { 5,7-дигидрокси-6,4'-диметоксифлавон } \\
\text { (пектолинаригенин) }\end{array}$ \\
\hline 109 & $\begin{array}{l}\text { 5,4'-дигидрокси-6,7-диметоксифлавон } \\
\text { (цирсимаритин) }\end{array}$ \\
\hline 110 & $\begin{array}{l}\text { 5-гидрокси-6,7,4'-триметоксифлавон } \\
\text { (сальвигенин) }\end{array}$ \\
\hline 111 & 5,7,2',6'-тетрагидроксифлавон \\
\hline 112 & 5,7, 2',6'-тетрагидроксифлавон 2'-O-Glcp \\
\hline 113 & $\begin{array}{l}\text { 5,7,8,4'-тетрагидроксифлавон } \\
\text { (изоскутеллареин) }\end{array}$ \\
\hline 114 & Изоскутеллареин-7-O-GlcAp (изоскутелларин) \\
\hline 115 & Изоскутеллареин-8-O-GlcAp \\
\hline 116 & $\begin{array}{l}\text { 5,7,4'-тригидрокси-8-метоксифлавон } \\
\text { (изодинатин) }\end{array}$ \\
\hline 117 & 5,4'-дигидрокси-7,8-диметоксифлавон \\
\hline 118 & $\begin{array}{l}\text { 5,7,3',4'-тетрагидроксифлавон } \\
\text { (лютеолин) }\end{array}$ \\
\hline 119 & Лютеолин-7-O-Glcp (цинарозид) \\
\hline 120 & Лютеолин-7-O-GlcAp \\
\hline 121 & Лютеолин-7-O-GalAp \\
\hline 122 & Лютеолин-7-O-(6"-Rhap)-Glcp \\
\hline 123 & Лютеолин-7-O-(6"-GlcAp)-GlcAp \\
\hline 124 & $\begin{array}{l}\text { 5,7,3'-тригидрокси-4'-метоксифлавон-7-O-Glcp } \\
\text { (диосметин-7-O-Glcp) }\end{array}$ \\
\hline 125 & 5-гидрокси-7,3',4'-триметоксифлавон \\
\hline 126 & 5,7,2',3'-тетрагидроксифлавон \\
\hline 127 & 5,7,2',3'-тетрагидроксифлавон-7-O-GlcAp \\
\hline 128 & 5,7,2',5'-тетрагидроксифлавон \\
\hline 129 & 5,7,2',5'-тетрагидроксифлавон 7-O-GlcAp \\
\hline 130 & 5,7,2'-тригидрокси-6'-метоксифлавон \\
\hline 131 & 5,7,6'-тригидрокси-2'-метоксифлавон \\
\hline 132 & 5,7,2',3'-тетраметоксифлавон \\
\hline 133 & 5,7,2',5'-тетраметоксифлавон \\
\hline 134 & 5,7,2',6'-тетраметоксифлавон \\
\hline 135 & $\begin{array}{l}\text { 5,6,7,3',4' пентагидроксифлавон } \\
\text { (6-оксилютеолин) }\end{array}$ \\
\hline 136 & 5,7,8,3',4'-пентагидроксифлавон (гиполаетин) \\
\hline 137 & 5,6,7,3',4'-пентагидроксифлавон-7-O-GlcAp \\
\hline 138 & 5,7,3',4'-тетрагидрокси-6-метоксифлавон \\
\hline
\end{tabular}

S1 [47], S2 [4], S3 [30], S4 [25], S5 [25], S9 [23, 25], S10 [8,

100, 103], S11 [4, 46], S12 [25], S13 [84], S15 [34, 36], S18

[38], S24 [24], S25 [25], S26 [41, 81], S28 [4], S29 [67, 68, 83],

S32 [4], S33 [73, 78], S36 [4], S45 [25], S47 [4], S46 [108], S48

[47], S49 [24], S50 [28,57,58], S54 [11, 25], S59 [47], S62 [25]

S11 $[25,46]$

S47 $[4,25]$

S1 [55], S3 [30], S7 [10], S9 [23, 25], S10 [8, 10,103], S13 [84], S26 [104], S32 [4], S36 [4, 10], S47 [25], S51 [24], S59 [4],

S60 [52]

S46 [108]

S10 [103], S26 [104], S32 [4, 25], S59 [4, 25], $\mathbf{S 4 7}$ [25]

S9 [4, 10], S37 [25], S40 [4], S47 [10], S56 [25]

$\mathbf{S} 47[4,25]$

$\mathbf{S} 47[4,25]$

S47 $[4,25]$

S11 $[8,28]$, S47 [10, 25]

S39 [60]

S9 [23]

S7 [8], S9 [8, 25, 71, 99], S39 [69], S63 [8]

S9 [23]

S9 [23, 25], S24 [42], S26 [8,41,104], S46 [8], S48 [25], S56

[25]

S9 [23], S26 [104], S48 [47], S54 [11]

S9 [8], S10 [103], S26 [8,41]

S3 [10, 30], S6 [80], S9 [8, 23, 25], S10 [8, 10, 103], S14 [10,

33, 77], S26 [8, 82, 104, 105], S46 [50], S49 [24], S51 [24], S63

[8]

S56 [25]

S1 [47], S2 [4], S8 [4], S9 [23, 10, 99], S10 [8, 10, 100, 103], S13 [84], S14 [8, 33], S15 [10, 34], S18 [10, 38], S26 [25, 41, 104, 105], S27 [72], S31 [43], S35 [4, 10], S37 [10], S47 [4],

S48 [47], S54 [10, 11], S56 [25], S59 [47]

S8 [4, 25], S15 [36], S26 [104], S34 [73], S35 [4], S47 [4], S59 $[4,8,25]$

S2 [4], S9 [23], S10 [103], S15 [34], S27 [72], S28 [4], S46 [8], S47 [4], S48 [25], S41 [63], S54 [4, 11], S59 [25] S60 [64]

S10 [103]. S26 [104]

S10 [101], S26 [104] S20 [96]

S44 [88]

S9 [4, 8, 25], S10 [8] S10 [103]

S6 [80], S9 [8, 24]

S6 [80]

S9 $[8,23,25]$

S9 [23]

S9 [23]

S9 [8, 23]

S9 $[8,23]$

S15 [4, 25, 34], S56 [25]

S9 [23], S56 [25]

S15 [25, 34], S54 [11]

S37 [10, 25] 
Окончание таблищь 2

\begin{tabular}{|c|c|c|}
\hline 1 & 2 & 3 \\
\hline 139 & $\begin{array}{l}\text { 6,7,3'-тригидрокси-5,4'-диметоксифлавон } \\
\text { (цирсилинеол) }\end{array}$ & S10 [8] \\
\hline 140 & 5,8,2'-тригидрокси-6,7-диметоксифлавон & S9 $[8,24,25]$ \\
\hline 141 & 5,6,2'-тригидрокси-7,8-диметоксифлавон & $\mathbf{S 1 0}[8,10], \mathbf{S 1 6}[71], \mathbf{S 1 8}[8,38]$ \\
\hline 142 & 5,7,2'-тригидрокси-6,8-диметоксифлавон & S51 $[24,25]$ \\
\hline 143 & 5,7,4'-тригидрокси-6,8-диметоксифлавон & S51 [24] \\
\hline 144 & $\begin{array}{l}\text { 5,2'-дигидрокси- } 6,7,8 \text {-триметоксифлавон } \\
\text { (тенаксин I) }\end{array}$ & S9 $[8,23,25], \mathbf{S 4 9}[24], \mathbf{S 6 1}[8,25]$ \\
\hline 145 & $\begin{array}{l}\text { 5,2',5'-тригидрокси-7,8-диметоксифлавон } \\
\text { (редерианин ) }\end{array}$ & $\mathbf{S 5 2}[8,23,25]$ \\
\hline 146 & 5,2',5'-тригидрокси-7,8-диметоксифлавон-5'-O-Glcp & S26 [104] \\
\hline 147 & 5,2',5'-тригидрокси-6,7-диметоксифлавон & S9 [23] \\
\hline 148 & $\begin{array}{l}\text { 5,2',6'-тригидрокси-7,8-диметоксифлавон } \\
\text { (висцидулин II) }\end{array}$ & $\begin{array}{c}\mathbf{S 1}[54], \mathbf{S 2}[25], \mathbf{S 9}[10,23,25,99], \mathbf{S 1 6}[37], \mathbf{S 2 6}[25,41,82], \\
\mathbf{S 6 3}[8,10]\end{array}$ \\
\hline 149 & Висцидулин II -2'-O-Glcp & S9 $[23,25]$ \\
\hline 150 & Висцидулин II -2'-O-GlcAp & $\mathbf{S 1 0}[8,74]$ \\
\hline 151 & 5,6,7,2',6'-пентагидроксифлавон & S9 [99] \\
\hline 152 & 5,2',6'-тригидрокси-6,7-диметоксифлавон & S9 [99] \\
\hline 153 & 5,2',6'-тригидрокси-6,7-диметоксифлавон -2'-O-Glcp & S9 $[8,23]$ \\
\hline 154 & 5,7,2'-тригидрокси-8,6'-диметоксифлавон & S9 $[8,23,25], \mathbf{S 1 4}[10,77]$ \\
\hline 155 & 5,7,6'-тригидрокси-8,2'-диметоксифлавон & S9 [23] \\
\hline 156 & 5,6'-дигидрокси-7,8,2'-триметоксифлавон & S9 [23] \\
\hline 157 & $\begin{array}{l}\text { 5,2'-дигидрокси-7,8,6'-триметоксифлавон } \\
\text { (ривулярин) }\end{array}$ & $\begin{array}{c}\mathbf{S 9}[8,23,24], \mathbf{S 1 0}[8,10,25], \mathbf{S 1 6}[25], \mathbf{S 2 0}[96], \mathbf{S 2 6}[8,41, \\
82], \mathbf{S 4 6}[50], \mathbf{S 4 9}[87]\end{array}$ \\
\hline 158 & Ривулярин-2'-O-GlcAp & S9 [23], S10 [8,74] \\
\hline 159 & 5,7-дигидрокси-8,2',6'-триметоксифлавон & $\mathbf{S 1 4}[8,33,77]$ \\
\hline 160 & $\begin{array}{l}\text { 5,7,2',6'-тетрагидрокси-8-метоксифлавон-2'-O- } \\
\text { (2"-OCaf)-Glcp }\end{array}$ & $\mathbf{S 1 4}[8,33]$ \\
\hline 161 & $\begin{array}{l}\text { 5-гидрокси-7,8,2',6'-тетраметоксифлавон (алти- } \\
\text { зин) }\end{array}$ & $\mathbf{S 5}[4,8,25], \mathbf{S 1 4}[10], \mathbf{S 1 8}[8,38]$ \\
\hline 162 & 5,7,2',5'-тетрагидрокси-8,6'-диметоксифлавон & $\mathbf{S 9}[8,23,25], \mathbf{S 5 2}[8], \mathbf{S 6 3}[25]$ \\
\hline 163 & 5,7,2',3'-тетрагидрокси-8,6'-диметоксифлавон & S9 [23] \\
\hline 164 & 5,7,2',6'-тетрагидрокси-8,3'-диметоксифлавон & S9 [23] \\
\hline 165 & 5,6,2',6'-тетрагидрокси-7,8-диметоксифлавон & $\mathbf{S 4 6}[8,50]$ \\
\hline 166 & 5,2'-дигидрокси-6,7,8,6'-тетраметоксифлавон & S9 [10, 25], $S 7$ [8] \\
\hline 167 & 5,2'-дигидрокси-6,7,8,3'-тетраметоксифлавон & S9 [23]. \\
\hline 168 & 5-гидрокси-6,7,8,2',6'-пентаметоксифлавон & S9 $[10,23,25]$ \\
\hline 169 & 5-гидрокси-7,8,2',5', 6'-пентаметоксифлавон & S9 [23] \\
\hline 170 & $\begin{array}{l}\text { 5,7,2',5'-тетрагидрокси-8,6'-диметоксифлавон } \\
\text { (висцидулин III) }\end{array}$ & S9 [8, 23, 25], S23 [8], S39 [69], S49 [24], S52 [25], S63 [8] \\
\hline 171 & 5,7,3' ,6'-тетрагидрокси-6,2'-диметоксифлавон & S9 [23] \\
\hline 172 & Висцидулин III-2'-O-Glcp & S9 $[8,23]$ \\
\hline 173 & 5,6,2'-тригидрокси-7,8,6'-триметоксифлавон & $\mathbf{S 4 6}[10,50]$ \\
\hline 174 & 5,2',6'-тригидрокси-6,7,8-триметоксифлавон & $\mathbf{S 1}$ [54], S2 [89] S3 [8, 30], S49 [75] \\
\hline 175 & $\begin{array}{l}\text { 5,2',6'-тригидрокси-6,7,8-триметоксифлавон-2'-O- } \\
\text { Glcp }\end{array}$ & $\mathbf{S 3}[10], S 9[8,23], \mathbf{S 2 0}[96]$ \\
\hline 176 & 5,2',5'-тригидрокси-6,7,8-триметоксифлавон & S9 $[8,10,25]$ \\
\hline 177 & 5,2',5'-тригидрокси-7,8,6'-триметоксифлавон & S9 [23] \\
\hline 178 & 5,7-дигидрокси-6,8,2',3'-тетраметоксифлавон & S9 [8] \\
\hline 179 & 6,2'-дигидрокси-5,7,8,6'-триметоксифлавон & S9 [8] \\
\hline 180 & 5,7-дигидрокси-8,2',3',6'-тетраметоксифлавон & S9 [97] \\
\hline 181 & $\begin{array}{l}\text { 5,2'-дигидрокси-6,7,8,6'-тетраметоксифлавон } \\
\text { (скуллкапфлавон II) }\end{array}$ & $\mathbf{S 7}[8,25], \mathbf{S 3}[30], \mathbf{S 9}[8,23,25,99], \mathbf{S 4 2}$ [106], $\mathbf{S 6 3}[8]$ \\
\hline 182 & 5,7,3',6'-тетрагидрокси-6,8,2'-триметоксифлавон & S39 [69] \\
\hline
\end{tabular}

"См. сокращения

На основании приведенных данных можно заключить, что байкалин, вогонин, ороксилин, скутеллареин, хризин - типичные для растений рода Scutellaria соединения. В растениях этого рода пока не обнаружены $C$-метильные и $C$-пренильные производные флавонов.

Флаваноны и флаванонолы в растениях рода Scutellaria распространены довольно широко. Из растений этого рода выделено 70 флаванонов и 9 флаванонолов (табл. 3). При сравнении структурного 
многообразия флаванонов и флаванонолов заметна тенденция к сохранению определенных типов замещения, представители которых составляют в количественном содержании доминирующие соединения: 5,7диокси-, 5,6,7-триокси-, 5,7,8-триокси-, 5,7,4'-триокси-, 5,6,7,4'-тетраокси-, 5,7,8,2'-тетраокси- и 5,7,3',4'тетраокси. Наиболее крупными являются типы дигидробайкалеина $(5,6,7)$, дигидроскутелляреина $\left(5,6,7,4^{\prime}\right)$ и эриодиктиола $\left(5,7,3^{\prime}, 4^{\prime}\right)$. Самый простой представитель этой группы соединений, найденный в растениях рода Scutellaria, - 5,7-диоксифлаванон (пиноцембрин), а самым окисленным представителем является (2S)5,6,7,2',3',4',5'-гептаметоксифлаванон. Часто встречаются метоксипроизводные флаванонов. Гликозиды флаванонов представлены 35 соединениями, среди них 19 глюкуронидов, 13 глюкозидов, два рутинозида и один неогесперидозид. Обнаружены 4 глюкозида флаванонола. Из S. baicalensis выделены 21 производный ди-, три-, тетра- и пентазамещенного флаванона и 3 флаванонола.

Многие флаваноны растений рода Scutellaria являются оптически активными и имеют $2 S$ конфигурацию хирального центра С-2 $[8,25]$. В растениях обнаружены также рацемические формы флаванонов,

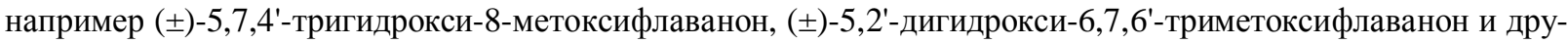
гие соединения. Большинство флаванонолов имеют $2 R, 3 R$-конфигурации хиральных центров.

Таблица 3. Флаваноны и флаванонолы рода Scutellaria L.

\begin{tabular}{|c|c|c|}
\hline $\begin{array}{l}\text { № } \\
\text { П/ח }\end{array}$ & Название флавоноида & Вид (номер согласно таблице 1), ссылка \\
\hline 1 & 2 & 3 \\
\hline 183 & 5,7-дигидроксифлаванон (пиноцембрин) & $\mathbf{S 5}$ [8], S9 [23], S14 [25] \\
\hline 184 & Пиноцембрин-7-O-GlcAp & S54 [11] \\
\hline 185 & (2S)-7-гидрокси-5-метоксифлаванон (алпинетин) & $\mathbf{S 6}$ [80], S10 [8], S26 [25], \\
\hline 186 & 5,6,7-тригидроксифлаванон (дигидробайкалеин) & S9 [23, 25, 99], , S15 [10, 34], S53 [76] \\
\hline 187 & 5,6-дигидрокси-7-метоксифлаванон & S9 [23] \\
\hline 188 & Дигидробайкалеин-7-O-GlcAp (дигидробайкалин) & $\begin{array}{c}\mathbf{S 7}[8], \mathbf{S 9}[8,23], \mathbf{S 1 5}[4,34], \mathbf{S 2 4}[24], \mathbf{S 4 9}[24], \\
\mathbf{S 5 3}[76], \mathbf{S 5 4}[11]\end{array}$ \\
\hline 189 & 5,7-дигидрокси-6-метоксифлаванон (дигидроороксилин А) & S9 [8, 23, 25, 99], S53 [76] \\
\hline 190 & Дигидроороксилин А 7-O-Glcp & S9 $[23,25]$ \\
\hline 191 & 5,7,8-тригидроксифлаванон (дигидронорвогонин) & $\mathbf{S 7}[8,10,25], \mathbf{S 1 5}[4,10], \mathbf{S 5 6}[25]$ \\
\hline 192 & Дигидронорвогонин 7-O-GlcAp & S9 [23], S15 [4, 25] \\
\hline 193 & 5,8-дигидрокси-7-метоксифлаванон & S9 [23] \\
\hline 194 & (2S)-5,7,2'-тригидроксифлаванон & $\mathbf{S 6}[80], \mathbf{S 2 6}[8,25,104]$ \\
\hline 195 & (2S)-5,7,2'-тригидроксифлаванон-7-O-Glcp & S49 [75] \\
\hline 196 & $(2 \mathrm{~S})-5,7,2$-тригидроксифлаванон-7-O-(6"-OMe)GlcAp & S49 [61] \\
\hline 197 & (2S)-5,7,2'-тригидроксифлаванон-7-O-(6"-OEt)GlcAp & S49 [61] \\
\hline 198 & (2S)-7,2'-дигидрокси-5-метоксифлаванон & S6 [80], S58 $[25,70]$ \\
\hline 199 & $(2 S)-7,2^{\prime}$-дигидрокси-5-метоксифлаванон 7-O-GlcAp & S6 [80] \\
\hline 200 & 5,7-дигидрокси-2'-метоксифлаванон & S15 [25] \\
\hline 201 & 5,7-дигидрокси-2'-метоксифлаванон -7-O-GlcAp & S15 [25] \\
\hline 202 & 5,7,4'-тригидроксифлаванон (нарингенин) & S9 $[23,25], \mathbf{S 1 0}[8,10,25], \mathbf{S 2 6}[104], \mathbf{S 5 8}[25,70]$ \\
\hline 203 & Нарингенин-7-O-(2"-Rhap)-Glcp (нарингин) & $\mathbf{S 1 0}[100]$ \\
\hline 204 & $\begin{array}{l}\text { 5,6,7,4'-тетрагидроксифлаванон } \\
\text { (изокартамидин, дигидроскутеллареин) }\end{array}$ & $\begin{array}{c}\mathbf{S 1}[25,47], \mathbf{S 9}[8,23,25], \mathbf{S 1 0}[8], \mathbf{S 4 8}[47], \mathbf{S 5 3} \\
{[8], \mathbf{S 5 6}[25], \mathbf{S 5 9}[47]}\end{array}$ \\
\hline 205 & Изокартамидин-7-O-GlcAp (дигидроскутелларин) & $\begin{array}{c}\mathbf{S 1}[25,47], \mathbf{S 9}[8,23,25], \mathbf{S 1 0}[74,103], \mathbf{S 2 6} \\
{[104], \mathbf{S 5 4}[11], \mathbf{S 5 9}[47]}\end{array}$ \\
\hline 206 & $\begin{array}{l}\text { 5,7,8,4'-тетрагидроксифлаванон (картамидин, дигидроизос- } \\
\text { кутелляреин) }\end{array}$ & S9 $[8,23,25], \mathbf{S 1 0}[8,103]$ \\
\hline 207 & Картамидин-7-O-GlcAp (дигидроизоскутеллярин) & S9 [8, 23], S10 [74,103], S26 [104] \\
\hline 208 & 5,7,4'-тригидрокси-6-метоксифлаванон (дигидрогиспидулин) & S9 [8, 23, 25], S10 [25, 103], S26 [104], S51 [25] \\
\hline 209 & Дигидрогиспидулин-7-O-GlcAp & S10 [103], S26 [104] \\
\hline 210 & (土)-5,7,4'-тригидрокси-8-метоксифлаванон & $\begin{array}{c}\mathbf{S 7}[8], \mathbf{S 9}[8], \mathbf{S 1 0}[8,25,103], \mathbf{S 2 6}[104], \mathbf{S 5 1} \\
{[25], \mathbf{S 5 8}[25,70]}\end{array}$ \\
\hline 211 & 5,7,4'-тригидрокси-8-метоксифлаванон-7-O-GlcAp & S10 [103] S26 [104] \\
\hline 212 & 5,7,2'-тригидрокси-6-метоксифлаванон-7-O-Glcp (амоенин В) & S7 [91] \\
\hline 213 & $\begin{array}{l}\text { 2(S)-5,7,2'-тригидрокси-8-метоксифлаванон } \\
\text { (дигидроскутевурин) }\end{array}$ & $\mathbf{S 2 6}[8,25]$ \\
\hline 214 & Дигидроскутевурин-7-O-GlcAp & $\mathbf{S 2 6}[104,105]$ \\
\hline 215 & (2S)-5,7-дигирокси-8, 2'-диметоксифлаванон & $\mathbf{S 7}[31], \mathbf{S 1 4}[8,10,91], \mathbf{S 2 6}[25], \mathbf{S 5 8}[25,70]$ \\
\hline 216 & 5,7-дигидрокси-8,2 ${ }^{1}$-диметоксидигидрофлаванон-7-O-GlcAp & S26 [104] \\
\hline
\end{tabular}


Окончание таблицы 3

\begin{tabular}{|c|c|c|}
\hline 1 & 2 & 3 \\
\hline 217 & (2S)-7-гидрокси-5,8, 2'-триметоксифлаванон & S9 $[23,25], \mathbf{S 1 4}[8,91]$ \\
\hline 218 & (2S)-5,7, 3',4'-тетрагидроксифлаванон (эриодиктиол) & $\mathbf{S 9}[8,23], \mathbf{S 1 0}[8,10,25]$ \\
\hline 219 & Эриодиктиол-7-O-GlcAp & S10 [103] \\
\hline 220 & 5,7,3'-тригидрокси-4'-метоксифлаванон (гесперетин) & S9 $[23,25]$ \\
\hline 221 & Гесперетин-7-O-(6"-Rhap)-Glcp (гесперидин) & S9 $[23,25]$ \\
\hline 222 & $\begin{array}{l}\text { 5,7-дигидрокси-3',4'-диметоксифлаванон-7-O-(6"-Rhap)-Glcp } \\
\text { (метилгесперидин) }\end{array}$ & S26 [104] \\
\hline 223 & $(2 S)-5,7,2^{\prime}, 5^{\prime}$-тетрагидроксифлаванон & S6 [80] \\
\hline 224 & $(2 S)-5,7,2^{\prime}, 5^{\prime}$-тетрагидроксифлаванон 7-O-Glcp & S6 [80] \\
\hline 225 & $(2 S)-5,7,2^{\prime}, 5^{\prime}$-тетрагидроксифлаванон 7-O-GlcAp & S6 [80] \\
\hline 226 & $(2 S)-5,7,2^{\prime}, 6$ '-тетрагидроксифлаванон & $\mathbf{S 7}[13,10], \mathbf{S 9}[8,23,25,71], \mathbf{S 6 3}[8]$ \\
\hline 227 & $(2 S)-7,2^{\prime}, 6^{\prime}$-тригидрокси-5-метоксифлаванон & $\mathbf{S 9}[8,23,25] \mathbf{S 2 6}[104]$ \\
\hline 228 & 7,2'-Дигидрокси-5,8-диметоксифлаванон & $\mathbf{S 1 0}[92]$ \\
\hline 229 & $(2 S)-5,2 ', 6$-тригидрокси-7-метоксифлаванон (скутеэмонин) & $\mathbf{S 7}[8,25], \mathbf{S 6 3}[8]$ \\
\hline 230 & $\begin{array}{l}(2 S)-5,2 ', 6 \text { '-тригидрокси-7-метоксифлаванон-2'-O-Glcp } \\
\text { (скутеэмоенозид) }\end{array}$ & S7 [8] \\
\hline 231 & (土)-5,2'-дигидрокси-6,7,6'-триметоксифлаванон & $\begin{array}{c}\text { S1 [55], S13 [32], S14 [8, 90], S20 [96], S24 [42], } \\
\text { S26 [25, 82], S41 [93] }\end{array}$ \\
\hline 232 & (+)-5,2'-дигидрокси-6,7,6'-триметоксифлаванон & $\mathbf{S 4 1}[45,93]$ \\
\hline 233 & $\begin{array}{l}\text { (-)-5,2'-дигидрокси-7,8,6'-триметоксифлаванон } \\
\text { (дигидроривуларин) }\end{array}$ & S14 [8] S26 [104] \\
\hline 234 & (土)-5,2'-дигидрокси-7,8,6'- триметоксифлаванон & $\mathbf{S 1 4}[10,90], \mathbf{S 2 6}[25,82]$ \\
\hline 235 & 5, 2',6'-тригидрокси-7,8-диметоксифлаванон-2 ${ }^{1}-O-G l c p$ & S26 [105] \\
\hline 236 & $\begin{array}{l}\text { 3,5,7,2',6'-пентагидроксифлаванон-7-O-GlcAp } \\
\text { (дигидровисцидулин I-7-O-GlcAp) }\end{array}$ & $\mathbf{S 1 0}[103]$ \\
\hline 237 & $(2 S) 5,2^{\prime}-$-дигирокси-7,8, 6'- триметоксифлаванон-2'- O-GlcAp & $\mathbf{S 2 6}[8,25]$ \\
\hline 238 & $(2 S)-5$-гидрокси-7,8, 2',6'-тетраметоксифлаванон & $\mathbf{S 1 8}[8,10,38]$ \\
\hline 239 & 5-гидрокси-6,7,8,4 ${ }^{1}$-тетраметоксифлаванон & S26 [105] \\
\hline 240 & $(2 S)-5,7,2^{\prime}, 5^{\prime}$-тетрагидрокси-6-метоксифлаванон & S53 $[8,76]$ \\
\hline 241 & $(2 S)-5,7,2$ ',5'-тетрагидрокси-6-метоксифлаванон -2'-O-Glcp & S53 $[8,76]$ \\
\hline 242 & $\begin{array}{l}\text { (2S)-5,7, 2',5'-тетрагидрокси-6-метоксифлаванон -2'-O- } \\
(2 " \text {-OFer)Glcp }\end{array}$ & $\mathbf{S 2 6}[104], \mathbf{S 5 3}[8,76]$ \\
\hline 243 & $\begin{array}{l}(2 S)-5,7,2 ', 5 \text { '-тетрагидрокси-6-метоксифлаванон -2'-O- } \\
(2 "-\text { OSin) Glcp }\end{array}$ & S53 $[8,76]$ \\
\hline 244 & $\begin{array}{l}\text { (2S)-5,7, 2',5'-тетрагидрокси-6-метоксифлаванон-2'-O- } \\
\left(2^{\prime \prime}-\text { OVan }\right) \text { Glcp }\end{array}$ & S53 $[8,76]$ \\
\hline 245 & $\begin{array}{l}\text { (2S)-5,2',5'-тригидрокси-7,8-диметоксифлаванон } \\
\text { (дигидроредерианин I) }\end{array}$ & $\mathbf{S 2 6}[8,25]$ \\
\hline 246 & $\begin{array}{l}(2 S)-5,2^{\prime}-\text {-игидрокси-7,8-диметоксифлаванон-2'-O-(6"- } \\
O M e) G l c A p \text { (скутеллариозид С) }\end{array}$ & $\mathbf{S 2 6}[105]$ \\
\hline 247 & $\begin{array}{l}(2 S)-5,7-д и г и д р о к с и-8,2^{\prime}-\text { диметоксифлаванон -7-O-Glcp } \\
\text { (скутеллариозид Е) }\end{array}$ & S26 [105] \\
\hline 248 & 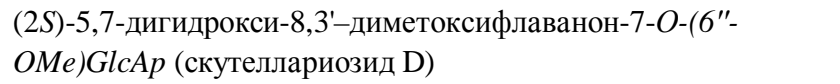 & S26 [105] \\
\hline 249 & 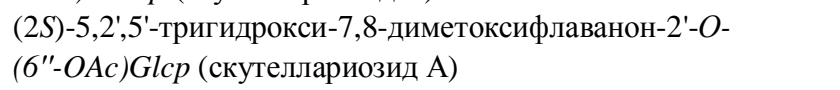 & S26 [105] \\
\hline 250 & $\begin{array}{l}(2 S)-5,2 ', 5 '-\text {-тригидрокси-7,8-диметоксифлаванон-2'-O- } \\
\left(3^{\prime \prime}-O-p-H b z\right) G l c p \text { (скутеллариозид В) }\end{array}$ & $\mathbf{S 2 6}[105]$ \\
\hline 251 & (-)-5,2'-дигидрокси-6,7,8,6'-тетраметоксифлаванон & S1 [55], S13 [32], S24 [42], S38 [28], S41 [93] \\
\hline 252 & (+)-5,2'-дигидрокси-6,7,8,6'-тетраметоксифлаванон & S41 [45] \\
\hline 253 & $(2 S)-5,6,7,2^{\prime}, 3^{\prime}, 4^{\prime}, 5^{\prime}-$-ептаметоксифлаванон & $\mathbf{S 2 6}[8,41]$ \\
\hline 254 & 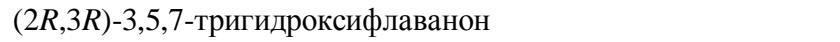 & $\mathbf{S 7}[8,10,25]$ \\
\hline 255 & $(2 R, 3 R)-3,5,7,2^{\prime}$-тетрагидроксифлаванон & $\mathbf{S 7}[8,10,25], \mathbf{S 6 3}[8]$ \\
\hline 256 & $(2 R, 3 R)-3,5,7,2$ ',6'-пентагидроксифлаванон & $\begin{array}{c}\mathbf{S 7}[8,25], \mathbf{S 9}[8,23,25,71,99], \mathbf{S 3 1}[43], \mathbf{S 6 1} \\
{[10], \mathbf{S 6 3}[8,10]}\end{array}$ \\
\hline 257 & $(2 R, 3 R)-3,5,7,2$ ',5'-пентагидроксифлаванон & S39 [69] \\
\hline 258 & 3,6,7, 2',6'-пентагидроксифлаванон & S9 [8] \\
\hline 259 & uзс-5,7, 2'-тригидроксифлаванонол-3-O-Glcp (амоэнин С) & S7 [91] \\
\hline 260 & $\begin{array}{l}\text { mранс-5,7, 2',6'-тетрагидроксифлаванонол 3-O-Glcp } \\
\text { (амоэнин D) }\end{array}$ & S7 [91] \\
\hline 261 & цис- 5,7, 2'6'-тетрагидроксифлаванонол 3-O-Glcp (амоэнин Е) & S7 [91] \\
\hline
\end{tabular}


Флавонолы, халконы и изофлавоны. Из растений рода Scutellaria L. выделены 13 производных флавонола, в том числе 5 гликозидов 3 биозида (табл. 4), относящиеся к 3,5,7-, 3,7,4'-, 3,5,7,4'-, 3,5,7,3',4'типам замещения. Висцидулин I (5,7,2',6'-пентагидроксифлавонол), обнаруженный в 6 видах растений рода Scutellaria L., имеет необычный для флавонолов 5,7,2',6' тип замещения. Известный флавоноловый гликозид рутин пока выделен только из S. baicalensi.

Халконы обнаружены в 6 видах растений, выделено 10 веществ, одно из которых является дигидрохалконом (табл. 5). Все 9 халконов являются гидрокси-, метокси-, метилендиоксипроизводными и содержат от 3 до 8 замещающих групп в кольцах А и В. Единственное производное дигидрохалкона - амоенин А является биозидом и имеет строение 2',4',6'-тригидроксидигидрохалкон 4'-O- $\beta$ - $D$-галактопиранозил-(1-2)$O-\beta$-D-глюкопиранозида [91]. К наиболее окисленным халконам относятся 2'-гидрокси-2,3,4,5,4',5',6'гептаметоксихалкон и 2,3,4,5,2',4',5',6'-октаметоксихалкон, содержащие в ароматических кольцах по 8 кислородных функций.

Изофлавоны представлены пятью соединениями, выделенными из растений S. baicalensis, S. scordiifolia (табл. 6). Все они содежат кислородные функции в положениях 7,4' ядра изофлавона.

Таблица 4. Флавонолы рода Scutellaria L.

\begin{tabular}{|c|c|c|}
\hline $\begin{array}{l}\text { № } \\
\text { ㅈ/ }\end{array}$ & Название флавоноида & Вид (номер согласно таблице 1), ссылка \\
\hline 262 & 7,4'-тригидроксифлавонол & S34 [73] \\
\hline 263 & 5-гидрокси-7-метоксифлавонол & $\mathbf{S 2 2}$ [40], S60 [62] \\
\hline 264 & 5,7-дигидрокси-3-метоксифлавон & S60 [62] \\
\hline 265 & 5,7-дигидрокси-4'-метоксифлавонол & S24 [24], S49 [24] \\
\hline 266 & 5,7,3',4'-тетрагидроксифлавонол (кверцетин) & $\mathbf{S 1}$ [55], S9 [23, 25], S13 [84] \\
\hline 267 & Кверцетин-3-O-Rhap (кверцитрин) & $\mathbf{S 1 0}[103]$ \\
\hline 268 & $\begin{array}{l}\text { 5,7,2',6'-тетрагидроксифлавонол } \\
\text { (висцидулин I) }\end{array}$ & $\begin{array}{c}\mathbf{S} 7[8,31], \mathbf{S 9}[8,23,25], \mathbf{S 2 3}[8], \mathbf{S 3 9}[69], \mathbf{S 6 1} \\
{[25], \mathbf{S 6 3}[25]}\end{array}$ \\
\hline 269 & 5,7,6'-тригидрокси-2'-метоксифлавонол & S9 [97] \\
\hline 270 & 5,2'-дигидрокси-7,8-диметоксифлавонол & S9 [99] \\
\hline 271 & $\begin{array}{l}\text { 5,7,2',6'-тетрагидроксифлавонол-2'-O-Glcp } \\
\text { (висцидулин I- 2'-O-Glcp) }\end{array}$ & $\mathbf{S 7}[8,31], \mathbf{S 9}[23,25]$ \\
\hline 272 & Кверцетин-3-O-(6"-Rhap)-Glcp (рутин) & S9 $[23,25]$ \\
\hline 273 & 5,7, 4'-тригидрокси-3'-метоксифлавонол-7-O-(Rhap)-Glcp & S49 [24] \\
\hline 274 & 5,3',4'-тригидрокси-7-метоксифлавонол-3-O-(Rhap)-Glcp & S49 [24] \\
\hline
\end{tabular}

Таблица 5. Халконы и дигидрохалконы Scutellaria L.

\begin{tabular}{|c|c|c|}
\hline $\begin{array}{l}\text { № } \\
\text { П/ח } \\
\end{array}$ & Название флавоноида & Вид (номер согласно таблице 1), ссылка \\
\hline 275 & 4,2',4'-тригидроксихалкон (изоликвиритигенин) & S39 [60] \\
\hline 276 & 2,2',4'-тригидрокси-6'-метоксихалкон & $\mathbf{S 5 8}[25,70]$ \\
\hline 277 & 2,6,2',4'-тетрагидрокси-6'-метоксихалкон & $\mathbf{S 9}[8,23,25]$ \\
\hline 278 & 2'-гидрокси- 2,3,4,5,4',5',6'-гептаметоксихалкон & $\mathbf{S 2 6}[8,41]$ \\
\hline 279 & 2,3,4,5,2',6'-гексаметокси-4',5'-метилендиоксихалкон & S26 $[8,41]$ \\
\hline 280 & $\begin{array}{l}\text { 2'-гидрокси 2,3,4,5,6'-пентаметокси-4',5'- } \\
\text { метилендиоксихалкон }\end{array}$ & $\mathbf{S 2 6}[8,41]$ \\
\hline 281 & $\begin{array}{l}\text { 2,2'-дигидрокси-3,4,5,6'-тетраметокси- 4',5'-метилен- } \\
\text { диоксихалкон }\end{array}$ & S26 $[8,41]$ \\
\hline 282 & 2',4'-дигидрокси-2,3',6'-триметоксихалкон & S14 $[8,90]$ \\
\hline 283 & 2,3,4,5,2', 4',5',6'-октаметоксихалкон & S26 $[8,41]$ \\
\hline 284 & $\begin{array}{l}\text { 2',4',6'-тригидроксидигидрохалкон 4'-O-(2"-Galp)-Glcp } \\
\text { (амоенин А) }\end{array}$ & S7 [91] \\
\hline
\end{tabular}

Таблица 6. Изофлавоны рода Scutellaria L.

\begin{tabular}{|c|c|c|}
\hline $\begin{array}{c}\text { № } \\
\text { П/П }\end{array}$ & Название флавоноида & Вид (номер согласно таблице 1), ссылка \\
\hline 285 & 7,4'-Дигидроксиизофлавон (даидзеин) & S9 $[23,25]$ \\
\hline 286 & Даидзеин-7-O-Glcp (даидзин) & $\mathbf{S 9}[23,25]$ \\
\hline 287 & 7-Гидрокси-4'-метоксиизофлавон (формононетин ) & S9 $[23,25]$ \\
\hline 288 & Формононетин-7-O-Glcp (ононин) & S54 [11] \\
\hline 289 & 7,4'-Дигидроксиизофлавон-8-C-Glcp (пуэрарин) & S9 $[23,25]$ \\
\hline
\end{tabular}


Флаволигнаны и бифлавоноиды. Флаволигнаны обнаружены только в $S$. prostrata, из которого выделены 7 представителей данного класса соединений, названные скутеллапростинами [8, 94, 108]. В этих соединениях фенилпропановая единица (конфериловый спирт) конденсирована с орто-дигидроксигруппой в положениях 7, 8 и 6, 7 кольца А соответствующего флавона, образуя 1,4-диоксановое кольцо. В скутеллапростинах А (290) и D (293) кольцо В незамещено, скутеллапростины В (291) и Е (294) содержат гидроксильные группы в положении 4', а скутеллапростины C (292), F (295) и М (296) - орто-дигидроксигруппы в положениях 3',4' кольца В.

Строение выделенных соединений установлено на основании изучения спектральных данных и таких химических превращений, как ацетилирование, щелочное расщепление, расщепление пиридиний бромидом. Щелочное расщепление скутеллопростинов A-F привело к образованию кониферилового спирта [3-(4-гидрокси-3-метоксифенил)пропен-1-ола].<smiles>[R]c1ccc(-c2cc(=O)c3c(O)c4c(cc3o2)O[C@H](CO)[C@@H](c2ccc(O)c(OC)c2)O4)cc1-c1cc(=O)c2c(O)cc3c(c2o1)O[C@H](C)[C@H](c1ccc(O)c(OC)c1)O3</smiles>

При расщеплении пиридиний бромидом соединений 290-295 образуются соответственно 28, 113, 136, 17, 95 и 135. Окислительным сочетанием 28, 113, 136, 17, 95 и 135 с конифериловым спиртом синтезированы 290-295, соответственно [94].

Из 5 видов рода выделены 5 бифлавоноида: 8,8'-бибайкалеин (297) [8, 30], аментофлавон (298) [8, 43], скутеллапбифлаванон (299) [108], (I-2S)-I-5,II-5,I-7,II-7,I-2',II-2',II-5'-гептагидрокси-[I-6,II-6']-флаванонилфлавон $\mathbf{( 3 0 0 )}$ и (I-2S)-I-5,II-5,I-7,II-7,I-2',II-2',I-5',II-5'-октагидрокси-[I-6,II-6']-флаванонилфлавон (301) [80]. Флавоноид 297 выделен из S. alpina и S. discolor, 298 - из S. linearis, 299 - из S. prostrata, 300 и 301 - из S. amabilis. Во всех выделенных бифлавоноидах флавоноидные звенья соединены друг с другом $C$ - $C$-связью. При установлении их структуры широко использованы возможности двумерной ЯМРспектроскопии [80].

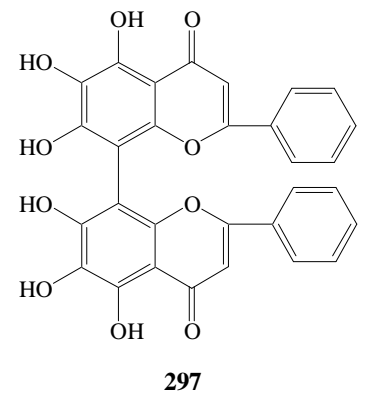<smiles>O=c1cc(-c2ccc(O)c(-c3c(O)cc(O)c4c(=O)cc(-c5ccc(O)cc5)oc34)c2)oc2cc(O)cc(O)c12</smiles>

298<smiles>O=C1CC(c2ccc(O)cc2)Oc2c(-c3ccc(O)c4c3OC(c3ccc(O)cc3)CC4=O)ccc(O)c21</smiles><smiles>[R]c1ccc(O)c([C@H]2CC(=O)c3c(cc(O)c(-c4c(O)ccc(O)c4-c4cc(=O)c5c(O)cc(O)cc5o4)c3O)O2)c1</smiles> 
В таблице 7 приведены данные о распределении флавоноидов в видах Scutellaria. Из данных таблицы видно, что флавоноиды отдельных видов отличаются по качественному составу, однако наиболее часто встречаются производные флавона (вогонин, ороксилин, байкалеин, апигенин, норвогонин, скутеллареин, лютеолин, гиспидулин и их гликозиды) и флаванона (дигидроскутеллареин, дигидробайкалеин, нарингенин, 5,7,4'-тригидрокси-8-метоксифлаванон, 5,2'-дигидрокси-6,7,6'-триметоксифлаванон 5,2'-дигидрокси6,7,8,6'-тетраметоксифлаванон, 3,5,7,2',6'-пентагидроксифлаванон) и их гликозиды. Халконы обнаружены в 6 видах растений, причем 5 из 10 соединений выделены из S. indica, тогда как изофлавоны найдены только в двух видах (S. scordiifolia, S. baicalensis). Флаволигнаны содержит только S. prostrata, а бифлавоноиды выделены из пяти видов Scutellaria.

Таблица 7. Флавоноиды видов Scutellaria

\begin{tabular}{|c|c|c|}
\hline № & Виды растений & Выделенные флавоноиды (номер флавоноида согласно таблице 2-6) \\
\hline 1 & 2 & 3 \\
\hline S1 & S. adenostegia & $\begin{array}{c}2,4,17,19,28,40,41,45,47,51,56,57,58,95,97,100,118,148,174,204,205,231 \\
251,266\end{array}$ \\
\hline $\mathrm{S} 2$ & S. adsurgens & $2,4,17,19,49,56,57,58,95,97,118,120,148,174$ \\
\hline S3 & S. alpina & $2,4,17,19,28,40,41,45,47,49,56,58,83,90,95,97,100,116,174,175,181,297$ \\
\hline S4 & S. altaica & 97 \\
\hline S5 & S. altissima & $17,19,40,41,45,47,95,97,161,183$ \\
\hline S6 & S. amabilis & $40,49,50,83,84,85,87,88,89,116,128,129,185,194,198,199,223,224,225,300,301$ \\
\hline S7 & S. amoena & $\begin{array}{c}2,4,9,10,17,18,19,28,40,41,45,47,48,75,76,77,78,100,111,181 \\
188,191,210,212,215,226,229,230,254,255,256,259,260,261,268,271,284\end{array}$ \\
\hline S8 & S. araxensis & $2,17,19,118,119$ \\
\hline S9 & S. baicalensis & $\begin{array}{c}1,2,3,4,8,9,10,11,14,17,19,20,21,23,24,25,26,28,29,35,36,40,41,42,44,45,47,48,49,56, \\
58,67,68,70,72,73,75,77,82,83,90,92,93,94,95,97,100,104,110,111,112,113,114,115, \\
116,118,120,126,128,130,131,132,133,134,136,140,144,147,148,149,151,152,153,154, \\
155,156,157,158,162,163,164,166,167,168,169,170,171,172,175,176,177,178,179,180, \\
181,183,186,187,188,189,190,192,193,202,204,205,206,207,208,210,217,218,220,221, \\
226,227,256,258,266,268,269,270,271,272,277,285,286,287,289\end{array}$ \\
\hline S10 & S. barbata & $\begin{array}{c}17,19,36,37,38,40,41,56,57,58,66,80,81,83,86,87,88,90,95,96,97,100,102,115,116, \\
118,120,122,123,126,127,139,141,150,157,158,185,202,203,204,205,206,207 \\
208,209,210,211,218,219,228,236,267\end{array}$ \\
\hline S11 & S. caucasica & $2,4,17,19,40,41,56,58,62,63,64,65,95,97,98,108$ \\
\hline $\mathrm{S} 12$ & S. columnae & 19,97 \\
\hline S13 & S. comosa & $2,4,5,17,19,28,40,41,45,47,54,56,57,95,97,100,118,231,251,266$ \\
\hline S14 & S. discolor & $\begin{array}{c}2,4,28,29,32,37,40,41,56,79,83,87,91,116,118,154,159,160,161,183,215,217 \\
231,233,234,282,297\end{array}$ \\
\hline S15 & S. galericulata & $\begin{array}{c}2,4,12,15,16,17,19,22,28,31,40,41,45,47,51,56,57,58,97,118,119,120,135,186 \\
188,191,192,200,201\end{array}$ \\
\hline S16 & S. glabrata & $2,4,18,40,90,141,148,157$ \\
\hline S17 & S. granulosa & $2,4,51,55$ \\
\hline S18 & S. grossa & $2,4,17,19,21,28,31,40,41,45,47,92,95,97,118,141,161,238$ \\
\hline S19 & S. guttata. & $2,5,40,45,56,57,95,96$ \\
\hline S20 & S. haematochlora & $124,157,175,231$ \\
\hline S21 & S. havanensis & 40 \\
\hline S22 & S. holosericea & $2,3,13,56,263$ \\
\hline S23 & S.hypericifolia & $17,45,170,268$ \\
\hline S24 & S. immaculata & $2,4,17,18,19,28,29,31,39,40,41,43,46,47,56,57,95,96,97,113,188,231,251,265$ \\
\hline S25 & S. incona & 97 \\
\hline S26 & S. indica & $\begin{array}{c}2,4,19,32,33,40,41,56,58,81,83,86,87,89,95,96,97,100,102,113,114,115,116 \\
118,119,122,123,146,148,157,185,194,202,205,207,208,209,210,211,213,214 \\
215,216,222,227,231,233,234,235,237,239,242,245,246,247,248,249,250,253,278 \\
279,280,281,283\end{array}$ \\
\hline S27 & S. iskanderi & $17,19,40,41,45,47,56,58,118,120$ \\
\hline S28 & S. karjaginii & $2,56,97,120$ \\
\hline S29 & S. lateriflora & $17,19,40,97$ \\
\hline S30 & S. likiangensis & 54,74 \\
\hline S31 & S. linearis & $2,40,41,56,118,256,298$ \\
\hline S32 & S. litwinowii & $17,19,45,47,79,95,97,100,102$ \\
\hline S33 & S. nepetoides & $31,32,34,58,97$ \\
\hline
\end{tabular}


Окончание таблицы 7

\begin{tabular}{|c|c|c|}
\hline 1 & 2 & 3 \\
\hline S34 & S. ocellata & $19,35,36,40,41,45,56,119,262$ \\
\hline S35 & S. oreophila & $2,17,19,118,119$ \\
\hline S36 & S. orientalis & $2,3,4,17,19,40,41,51,56,95,97,100$ \\
\hline S37 & S. ovata & $2,27,46,56,104,118,138$ \\
\hline S38 & S. oxystegia & $2,45,251$ \\
\hline S39 & S. pekinensis & $4,10,11,17,18,19,28,40,41,52,56,90,109,111,170,182,257,268,275$ \\
\hline $\mathrm{S} 40$ & S. pekinensis var. ussuriensis & $28,36,37,104,148$ \\
\hline S41 & S. phyllostachya & $2,5,17,18,28,29,40,41,47,51,57,58,96,120,231,232,251,252$ \\
\hline S42 & S. pinnatifida. & 40, 181 \\
\hline S43 & S. platystegia & 57 \\
\hline S44 & S. pontica & $56,57,60,64,125$ \\
\hline S45 & S. prilipkoana & 97 \\
\hline S46 & S. prostrata & $\begin{array}{c}2,4,17,19,28,31,40,41,45,47,49,51,55,56,58,63,83,86,90,97,101,113,116,120, \\
157,165,173,290,291,292,293,294,295,296,299\end{array}$ \\
\hline S47 & S. przewalskii & $2,19,56,57,58,95,96,97,99,100,103,104,105,106,107,108,118,119,120$ \\
\hline S48 & S. pycnoclada & $2,4,17,19,49,54,56,58,95,97,113,114,118,120,204$ \\
\hline S49 & S. ramosissima & $\begin{array}{c}2,4,11,17,19,28,31, \begin{array}{c}40,41,45,46,47,53,71,97,116,144,157,170,174 \\
188,195,196,197,265,273,274\end{array}\end{array}$ \\
\hline S50 & S. regeliana var.ikonnikovii & $4,19,30,31,32,54,74,97$ \\
\hline S51 & S.repens & $68,69,100,116,142,143,208,210$ \\
\hline S52 & S. rehderiana & $17,40,45,95,145,162,170$ \\
\hline S53 & S. scandens & $2,4,17,19,28,40,41,45,186,188,189,204,240,241,242,243,244$ \\
\hline S54 & S. scordiifolia & $2,4,17,19,31,40,41,45,47,51,55,56,57,58,95,97,114,118,120,184,188,205,288$ \\
\hline S55 & S. seleriana & 45 \\
\hline S56 & S. sevanensis & $2,17,40,45,49,51,56,63,68,73,95,104,113,117,118,135,136,191,204$ \\
\hline S57 & S. squarrosa & $2,17,19,40,45,47$ \\
\hline S58 & S. strigillosa & $2,17,19,28,35,40,41,45,49,51,56,87,198,202,210,215,276$ \\
\hline S59 & S. supina & $2,4,17,19,28,40,41,45,46,47,56,57,58,61,79,95,97,100,102,118,119,120,204$ \\
\hline S60 & S. schachristanica & $2,4,5,6,7,40,45,56,57,58,59,95,96,100,121,263,264$ \\
\hline S61 & S. tenax & $17,40,45,144,256,268$ \\
\hline S62 & S. tournefortii & $49,54,95,97$ \\
\hline S63 & S. viscidula & $2,17,19,28,40,41,45,75,95,111,116,162,170,181,226,229,255,256,268$ \\
\hline
\end{tabular}

Флавоноиды культуры тканей. В связи с исключительной ценностью корней шлемника байкальского, относительно малыми природными запасами, медленными темпами роста растений в естественных зарослях (5-10 лет) и сложностью выращивания экологически чистого сырья возникла необходимость получения культуры в условиях in vitro. С 80-х гг. прошлого века проводятся исследования культуры ткани корня S. baicalensis и изучается ее химический состав [109-117]. Качественный состав флавонов культивиpуемых корней S. baicalensis в основном представлен теми же, которые накапливаются в корнях целого дифференцированного растения: байкалином (19), вогонозидом (41), байкалеином (17) и вогонином (40). Основными среди флавонов культуры ткани корня является 19. Однако концентрация флавонов в культуре корней остается до настоящего времени почти в 3 раза ниже концентрации флавонов в корнях целого растения. Установлено присутствие 17 флавонов, в том числе соединений, не обнаруженных в исходном растении, например, 112, 149, 158 и 167.

В работе [118] сообщается об изучении динамики накопления флавоноидов и других природных компонентов $S$. baicalensis в зависимости от периода вегетации растения. Установлено, что наибольшее содержание биологически активных соединений наблюдается в фазу цветения. Выявлено наличие линейных и нелинейных корреляций между содержанием некоторых элементов ( $\mathrm{Ba}, \mathrm{Co}, \mathrm{Cu}, \mathrm{Mo} \mathrm{и} \mathrm{др.)} \mathrm{и} \mathrm{флаво-}$ ноидов, а также показано, что состав почвы сказывается на количественном содержании ряда веществ в надземной части растения.

\section{Заключение}

Растения рода Scutellaria L. являются богатым источником уникальных флавоноидов, обладающих ценными фармакологическими свойствами. Виды Scutellaria L. представляют интерес как источник сырья, содержащего флавоноиды. Наибольшое количество флавоноидов выделено из растений S. baicalensis 
S. indica, S. barbata, S. amoena, S. prastrat, S. galericulata, S. discolor, S. ramosissima и S. supina. Среди выделенных флавоноидов доминируют флавоны и флаваноны, что, вероятно, связано с особенностями их биосинтеза. Представлены данные о составе флавоноидов 63 видов шлемника, о распространении в растениях, структуре и источниках получения 301 флавоноида, относящегося к группам флавонов, флаванонов, флаванонолов, флавонолов, халконов, изофлавонов, флаволигнанов и бифлавоноидов. Наукометрические исследования свидетельствуют о постоянно растущем интересе к изучению видов рода Scutellaria L. co cтороны фитохимиков, биологов, фармакологов и др. Приведенные в обзоре сведения могут быть использованы для решения вопросов хемосистематики растений изученного рода, а также в качестве справочной литературы для фитохимиков, биологов и фармакологов. Исследование флавоноидов перспективных видов Scutellaria L., выявление зависимости между их молекулярными и структурными параметрами, установление закономерностей в ряду структура - биологическая активность и изыскание путей применения в медицинской практике относятся к актуальным задачам современной фитохимии.

\section{Список литературы}

1. Юзепчук C.В. Шлемник - Scutellaria L. // Флора CССР. М.; Л., 1954. Т. XX. С. 72-225.

2. Род Scutellaria L. - шлемник [Электронный ресурc]. URL: http://survinat.ru/2011/04/rod_scutellaria_1__shlemnik/\#ixzz1cFzg2tVm

3. Шлемник байкальский (Scutellaria baicalensis) [Электронный pecypc]. URL: http://viktorovm.ru/vek-zdorovya3/zdorovyj-son-ili-spokojstvie-dnem-i-nochyu/narodnyj-travnik/

4. Растительные ресурсы СССР. Цветковые растения, их химический состав, использование. Семейства Нippuridaceae-Lobeliacae. СПб., 1991. С. 85-90.

5. Асеева Т.А., Батуев Б.Б., Ханкин И.С., Федотовских Н.Н., Дашнев Д.Б. Изучение тибетских многокомпонентных лекарственных смесей // Растительные ресурсы. 1985. Т. 21, вып. 1. С. 15-25.

6. Ибрагимов Ф.И., Ибрагимова В.С. Основные лекарственные средства китайской медицины. М., 1960. 412 с.

7. Минаева В.Г. Шлемник байкальский Scutellaria baicalensis Georgi. Лекарственные растения Сибири. Новосибирск, 1991. С. 212-214.

8. Shang X., He X., He X., Li M., Zhang R., Fan P., Zhang Q., Jia Z. The genus Scutellaria an ethnopharmacological and phytochemical review // J. Ethnopharmacol. 2010. Vol. 128. Pp. 279-313.

9. Гольдберг Е.Д., Дыгай А.М., Литвиненко В.И., Попова Т.П., Суслов Н.И. Шлемник байкальский. Фитохимия и фармакологические свойства. Томск, 1994. 222 с.

10. Чемесова И.И. Флавоноиды видов рода Scutellaria L. // Растительные ресурсы. 1993. Т. 29, вып. 2. С. 89-99.

11. Olennikov D.N., Chirikova N.K. Phenolic compounds and cinnamamide from Scutellaria scordiifolia // Chem. Nat. Comp. 2013. Vol. 49. Pp. 124-126.

12. Атлас ареалов и ресурсов лекарственных растений. М., 1976. 340 с.

13. Литвиненко В.И., Попова Т.П., Воловик В.Г., Гольдберг Е.Д., Дыгай А.М., Суслов Н.И. Фитохимия и фармакологические свойства препаратов шлемника байкальского. Харьков, 2007. 763 с.

14. Чирикова Н.К., Оленников Д.Н., Танхаева Л.М. Фармакогностическое исследование надземной части шлемника байкальского (Scutellaria. baicalensis. Georg.) // Химия растительного сырья. 2009. №1. С. 73-78.

15. Тараховский Ю.С., Ким Ю.А., Абдрасилов Б.С., Музафаров Е.Н. Флавоноиды: биохимия, биофизика, медицина. Пущино, 2013. 310 с.

16. Parajuli P., Joshee N., Rimando A., Mittal S., Yadav A.K. In vitro antitumor mechanisms of various Scutellaria extracts and constituent flavonoids // Planta Med. 2009. Vol. 75. Pp. 41-48.

17. Li-Weber M. New therapeutic aspects of flavones: the anticancer properties of Scutellaria and its main active constituents wogonin, baicalein and baicalin // Cancer Treat. Rev. 2009. Vol. 35. Pp. 57-68.

18. Yu, J.Q., Liu, H.B., Lei, J.C., Tan, W.J., Hu, X.M., Zou, G.L. Antitumor activity of chloroform fraction of Scutellaria barbata and its active constituents // Phytotherapy Research 2007. Vol. 21. Pp. 817-822.

19. Sonoda M., Nishiyama T., Matsukawa Y., Moriyasu M. Cytotoxic activities of flavonoids from two Scutellaria plants in Chinese medicine // J. Ethnopharmacol. 2004. Vol. 91. Pp. 65-68.

20. Gao Z., Huang K., Yang X., Xu H. Free radical scavenging and antioxidant activities of flavonoids extracted from the radix of Scutellaria baicalensis Georgi. // Biochim. Biophys. Acta. 1999. Vol. 1472, N3. Pp. 643-650.

21. Park H.G., Yoon S.Y., Choi J.Y., Lee G.S., Choi J.H., Shin C.Y., Son K.H., Lee, Y.S., Kim, W.K., Ryu J.H., Ko K.H., Cheong J.H. Anticonvulsant effect of wogonin isolated from Scutellaria baicalensis // European J. Pharmacology. 2007. Vol. 574. Pp. 112-119.

22. Флора Узбекистана. Ташкент, 1961. Т. 5. С. 270-284.

23. Оленников Д.Н., Чирикова Н.К., Танхаева Л.М. Фенольные соединения шлемника байкальского (Scutellaria baicalensis Georgi) // Химия растительного сырья. 2009. №4. С. 89-98.

24. Mamadalieva N.Z., Herrmann F., El-Readi M.Z., Tahrani A., Hamoud R., Egamberdieva D.R., Azimova S.S., Wink M. Flavonoids in Scutellaria immaculata and S. ramosissima (Lamiaceae) and their biological activity // J. Pharm. Pharmacol. 2011. Vol. 63, N10. Pp. 1346-1357. 
25. Маликов B.M, Юлдашев М.П. Фенольные соединения растений рода Scutellaria L.: распространение, строение и свойства // Химия природных соединений. 2002. №4. С. 299-324; 2002. №5. С. 385-407.

26. Куцык А.В., Середа А.В., Попова Т.П., Рыбаченко А.И., Литвиненко В.И. Спектро-фотометрическое определение флавоноидов в траве шлемника байкальского // Фармаком. 1998. №2. С. 18-20.

27. Чирикова Н.К., Оленников Д.Н., Танхаева Л.М. Определение количественного содержания флавоноидов в надземной части шлемника байкальского (Scutellaria baicalensis) // Химия растительного сырья. 2009. №4. C. 99-105.

28. Растительные ресурсы России и сопредельных государств. СПб., 1996. С. 303-304.

29. Valant-Vetschera K.M., Wollenweber E. Flavones and Flavonols // Flavonoids. Chemistry, Biochemistry and Application. Ed. by Andersen Q.M., Markham K.R. New-York: Taylor and Francis Group. 2006. Pp. 617-748.

30. Kikuchi Y., Miyaichi Y., Yamagnchi Y., Kizu H., Tomimori T., Vetschera K. Studies on the constituents of scutellaria species. XIV On the constituents of the roots and the leaves of Scutellaria alpina L. // Chem.Pharm. Bull. 1991. Vol. 39. Pp. 199-201.

31. Zhou Z.H., Zhang Y.J., Yang Ch. R. New flavonoid glycosides from Scutellaria amoena. Advances in Plant Glycosides, Chemistry and Biology. Amsterdam: Elsevier. 1999. Pp. 305-310.

32. Юлдашев М.П., Батиров Э.Х., Маликов В.М. Флавоноиды корней Scutellaria comosa // Химия природных соединений. 1996. №4. С. 610-612.

33. Tomimori T., Miyaichi Y., Imoto Y.Kizu H., Namba T. Studies on the Nepalese Crude Drugs. XI. On the Flavonoid Constituents of the Aerial Parts of Scutellaria discolor Colebr // Chem. Pharm. Bull. 1988. Vol. 36. Pp. 3654-3658.

34. Попова Т.П., Пакалн Д.А., Литвиненко В.И., Флавоноиды Scutellaria galericulata // Химия природных соединений. 1975. №1. С. 97-98.

35. Дудецкая Н. А., Теслов Л. С., Анисимова Н. А. Флавоноидный состав видов рода Scutellaria (Lamiaceae) флоры России // Растительные ресурсы. 2010. Т. 52, вып.1. С. 125-143.

36. Дудецкая Н.А., Теслов Л.С., Сипкина Н.Ю. Состав и содержание фенольных соединений в надземной части Scutellaria galericulata (Lamiaceae) // Растительные ресурсы. 2011. Т. 59, вып. 4. C. 96-106.

37. Юлдашев М.П., Маликов В.М. Флавоноиды надземной части Scutellaria glabrata // Химия природных соединений. 1993. №3. С. 471.

38. Kikuchi Y., Miyaichi Y., Tomimori T. Studies on Nepalese crude drags. XIII. On the flavonoids and iridoid constituents of the root of Scutellaria grossa Wall. // Chem. Pham. Bull. 1991. Vol. 39. Pp. 1051-1054.

39. Ташматов 3.О., Эшбакова К.А. Флавоноиды надземной части Scutellaria guttata // Фенольные соединения: фундаментальные и прикладные аспекты: материалы докладов VIII межд. симп. М., 2012. С. 668-675.

40. Kamoldinov Kh.Sh., Eshbakova K.A., Bobakulov Kh.M. Constituents of Scutellaria holosericea // Chem. Nat. Comp. 2012. Vol. 48. Pp. 889-890.

41. Miyaichi Y., Imoto Y., Tomimori T. Lin C-C. Studies on the constituents of Scutellaria species XI. On the flavonoid constituents of the aerial parts of Scutellaria indica L. // Chem. Pharm. Bull. 1987. Vol. 35. Pp. 3720-3725.

42. Юлдашев М.П., Каримов А. Флавоноиды корней Scutellaria immaculata // Химия природных соединений. 2005. №1. C. 26-28.

43. Hussain H., Ahmad V.U., Anwar S., Miana G.A., Krohn K. Chemical constituents of Scutellaria linearis // Biochem. Syst. Ecol. 2008. Vol. 36. Pp. 490-492.

44. Oganesyan G.B. Phenolic compounds from the aerial part of Scutellaria orientalis // Chem. Nat. Comp. 2010. Vol. 46. Pp. 466-467.

45. Сиддиков Г.У., Юлдашев М.П., Арипова С.Ф., Вдовин А.Д., Абдуллаев Н.Д., Ботиров Э.Х. Новые флаваноны корней Scutellaria phyllostachya // Химия природных соединений. 2008. №1. С. 24-25.

46. Давыдов В.С., Никитина Г.К., Бандюкова В.А. Флавоноиды надземной части Scutellaria polyodon Juz. // Растительные ресурсы. 1991. Т. 27, вып. 2. С. 50-54.

47. Насруллаев Ф.Д. Флавоны некоторых видов Scutellaria и Lagochilus семейство Labiatae : автореф. дис. ... канд. хим. наук. Ташкент, 1993. 24 с.

48. Мурадов Р., Абдуллаев Ш. В. Флавоноиды корней Scutellaria sguarrosa // Химия природных соединений. 1990. №4. C. 546-547.

49. Miyaichi Y., Morimoto T., Yaguchi K., Kizu H. Studies on the constituents of Scutellaria species (XXI): constituents of the leaves of Scutellaria strigillosa Hemsley // J. Nature Medicine. 2006. Vol. 60. Pp. 157-158.

50. Попова Т.П., Пакалн Д.А., Черных Н.А., Зос И.Г., Литвиненко В.И. Внутривидовая изменчивость фенольных соединений шлемника обыкновенного // Растительные ресурсы. 1976. Т. 12, вып. 2. С. 232-236.

51. Chirikova N.K., Olennikov D.N. New O- and C-glycosides from Scutellaria galericulata growing in Yakutia // $\mathrm{X}^{\text {th }}$ Inter. Symp. on the Chemistry of Natur. Compounds: Abstracts. Tashkent - Bukhara, 2013. P. 367.

52. Ташматов 3.О., Эшбакова К.А., Бобакулов Х.М., Абдуллаев Н.Д. Флавоноиды надземной части Scutellaria schachristanica // Химия природных соединений. 2009. №6. С. 737-738.

53. Wang H.Y., Xiao L.H., Liu L. Study on the chemical constitutes of the roots of Scutellaria viscidula Bunge. // J. Shenyang Pharm. University. 2003. Vol. 20. Pp. 399-403.

54. Chemesova I.I., Iinuma M., Budantsev A.L. Investigation of the flavonoid composition of Scutellaria adenostegia // Chem. Nat. Comp. 1993. Vol. 29. Pp. 133-134.

55. Каримов А.М., Юлдашев М.П., Ботиров Э.Х. Флавоноиды Scutellaria adenostegia Briq. // Химия растительного сырья. 2015. №1. С. 63-68. 
56. Юлдашев М.П., Батиров Э.Х., Маликов В.М. Флавоноиды корней Scutellaria comosa // Химия природных соединений. 1996. №4. С. 610-612.

57. Wang Y.Q., Matsuzaki K., Takahashi K., Okuyama T., Shibata S. Studies of the constitutents of Scutellaria I: the flavonoid glucuronides of "Bo ye huang chin", Scutellaria iconnikovii Juz. // Chem. Pharm. Bull. 1988. Vol. 36. Pp. 3206-3209.

58. Wang Y.Q., Matsuzaki K., Takahashi K., Okuyama T., Shibata S. Studies of the constitutents of Scutellaria. IV High performance liguid chromatography of glucuronylflavonoids of Scutellaria iconnikovii Juz. // Acta Pharm. Sinica. 1991. Vol. 26(5). Pp. 358-361.

59. Юлдашев М.П. Флавоноиды надземной части Scutellaria immaculata // Химия природных соединений. 2001. №5. C. 364-366.

60. Zhang Y.Y., Guo Y.Z., Ageta H., Harigaya Y., Onda M., Hashimoto K., Ikeya Y., Okada M., Maruno M. Studies on the Constituents of Aerial Parts of Scutellaria planipes // J. Chinese Pharm. Sciences. 1998. Vol. 7(2). Pp. 100-102.

61. Юлдашев М.П., Батиров Э.Х., Маликов В.М. Флавоноиды надземной части Scutellaria ramosissima // Химия природных соединений. 1992. №2. С. 178-182.

62. Ташматов 3.О., Эшбакова К.А., Бобакулов Х.М. Химические компоненты надземной части Scutellaria schachristanica // Химия природных соединений. 2011. С. 392-393.

63. Сиддиков Г.У., Юлдашев М.П., Абдуллаев Ш.В. Флавоноиды корней Scutellaria phyllostachya // Химия природных соединений. 2007. №3 С. 270-271.

64. Eshbakova K.A., Toshmatov Z.O., Yili A., Aisa H.A., Abdullaev N.D. Flavonoid galacturonides and glucuronide from the aerial part of Scutellaria schachristanica // Chem. Nat. Comp. 2013. Vol. 49. Pp. 103-105.

65. Ташматов 3.О., Эшбакова К.А., Бобакулов Х.М. Новый флавоновый гликозид из надземной части Scutellaria schachristanica // Химия природных соединений. 2011. С. 487-488.

66. Yu J.Q., Liu H.B., Lei J.C., Tan W.J., Hu X.M., Zou G.L. Antitumor activity of chloroform fraction of Scutellaria barbata and its active constituents // Phytotherapy Research. 2007. Vol. 21. Pp. 817-822.

67. Awad R., Arnason J.T., Trudeau V., Bergeron C., Budzinski J.W., Foster B.C., Merali Z. Phytochemical and biological analysis of Skullcap (Scutellaria lateriflora L.): a medicinal plant with anxiolytic properties // Phytomedicine. 2003. Vol. 10. Pp. 640-649.

68. Zhang Z.Z., Lian X.Y., Li S.Y., Stringer J.L. Characterization of chemical ingredients and anticonvulsant activity of American skullcap (Scutellaria lateriflora) // Phytomedicine. 2009. Vol. 16. Pp. 485-493.

69. Zhang Y.Y., Guo Y.Z., Ageta H., Harigaya Y., Onda M., Hashimoto K., Ikeya Y., Okada M., Maruno M. Studies on the Constituents of Roots of Scutellaria planipes // Planta Medica. 1997. Vol. 63(6). Pp. 536-539.

70. Miyaichi Y., Ishii K., Kuno T., Tomimori T. Studies on the constituents of Scutellaria species (XX): constituents of the roots of Scutellaria strigillosa Hemsley // Natrual Medicines. 1999. Vol. 53. Pp. 237-241.

71. Юлдашев М.П., Ботиров Э.Х., Маликов В.М. Флаваноиды Scutellaria baicalensis и Scutellaria glabrata // Химия природных соединений. 1994. №6. С. 822-823

72. Исмаилов А.И., Каримжонов А.К., Худайбергенов Т., Литвиненко В.И., Попова Т.П. Фенольные соединения Scutellaria iscanderi // Химия природных соединений. 1995. №3. С. 500-501.

73. Каримов А., Юлдашев М.П. Флавоноиды Scutellaria ocellata и S. nepetoides // Химия природных соединений. 2001. №5. C. 367-369.

74. Tomimori T., Imoto Y., Miyaichi Y. Studies on the constituents of Scutellaria species. XIII. On the Flavonoid constituents of the Root of Scutellaria rivularis Wall. // Chem. Pharm. Bull. 1990. Vol. 38. Pp. 3488-3490.

75. Юлдашев М.П., Батиров Э.Х., Нигматуллаев А., Маликов В.М. Строение двух новых флавоноидов из Scutellaria ramosissima // Химия природных соединений. 1994. №3. С. 355-359.

76. Miyaichi Y., Imoto Y., Tomimori T., Namba T. Studies on the Nepalese crude drugs. IX. On the flavonoid constituents of the root of Scutellaria scandens // Chem. Pharm. Bull. 1988. Vol. 36. Pp. 2371-2376.

77. Tomimori T., Miyaichi Y., Imoto Y., Kizu H., Namba T. Studies on the Nepalese Crude Drugs. VI.On the Flavonoid Constituents of the Root of Scutellaria discolor Colebr. // Chem. Pharm. Bull. 1986. Vol. 34. Pp. 406-408.

78. Каримов А., Муродов Р., Абдуллаев Ш.В., Попова Т.П., Литвиненко В.И. Флавоноиды Scutellaria nepetoides // Химия природных соединений. 1999. Спец. вып. С. 45-46.

79. Каримов А., Юлдашев М.П., Абдуллаев Ш.В., Ботиров Э.Х. Строение непетозида А из Scutellaria nepetoides // Химия природных соединений. 2000. Спец. вып. С. 18-19.

80. Miyaichi Y., Hanamitsu E., Kizu H., Tomimori T. Studies on the Constituents of Scutellaria Species (XXII). Constituents of the Roots of Scutellaria amabilis Hara. // Chem. Pharm. Bull. 2006. Vol. 54. Pp. 435-441.

81. Miyaichi Y., Imoto Y., Tomimori T. Lin C-C. Studies on the constituents of Scutellaria species XI. On the flavonoid constituents of the aerial parts of Scutellaria indica L. // Chem. Pharm. Bull. 1987. Vol. 35. Pp. 3720-3725.

82. Miyaichi, Y., Kizu, H., Tomimori, T., Lin, C.C. Studies on the constituents of Scutellaria species on the flavonoid constituents of the aerial parts of Scutellaria indica L. // Chem. Pharm. Bull. 1989. Vol. 39. Pp. 794-797.

83. Makino, T., Hishida, A., Goda, Y., Mizukami, H. Comparison of the major flavonoid content of S. baicalensis, S. lateriflora and their commercial products // J. Nature Medicine. 2008. Vol. 62. Pp. 294-299.

84. Юлдашев М.П. Флавоноиды надземной части Scutellaria comosa // Химия природных соединений. 1999. №2. С. 239-240.

85. Чемесова И.И., Иинума М., Буданцев А.Л., Анохина Б.О. Флавоноиды Scutellaria oxystegia Juz. // Растительные ресурсы. 1993. Т. 29, вып 4. С. 75. 
86. Чемесова И.И., Иинума М., Буданцев А.Л., Анохина Б.О. Флавоноиды Scutellaria phyllostachya Juz. // Растительные ресурсы. 1994. Т. 30, №1-2. С. 78.

87. Юлдашев М.П., Батиров Э.Х., Маликов В.М. Новый флавонгликозид из Scutellaria ramosissima // Химия природных соединений. 1995. №2. С. 317-318.

88. Ersöz T., Harput Ü.Ş., Saracoğlu İ., çaliş İ., Ogihara Y. Phenolic compounds from Scutellaria pontica // Turk J. Chem. 2002. Vol. 26. Pp. 581-588.

89. Чемесова И.И., Буданцев А.Л. Флавоноид из Scutellaria adsurgens // Химия природных соединений. 1994. №2. C. $287-288$.

90. Tomimori T., Miyaichi Y., Imoto Y., Kizu H., Namba T. Studies on the Nepalese Crude Drugs. VI.On the Flavonoid Constituents of the Root of Scutellaria discolor Colebr. // Chem. Pharm. Bull. 1985. Vol. 33. Pp. 4457-4463.

91. Zhou Z.H., Yang C.R. Five new flavonoid glycosides from Scutellaria amoena // Acta Botanica Yunnanica. 2000. Vol. 22. Pp. 475-481.

92. Wang G., Wang F., Liu J.-K. Two New Phenols from Scutellaria barbata // Molecules. 2011. Vol. 16. Pp. 1402-1408.

93. Сиддиков Г.У., Юлдашев М.П., Ботиров Э.Х., Абдуллаев Ш.В. Флавоноиды корней Scutellaria cordifrons и Scutellaria phyllostachya // Химия природных соединений. 2006. №3. С. 293.

94. Kikuchi Y., Miyaichi Y., Tomimori T. Studies on the Nepalese crude drugs. XIV. New Flavonoids from the root of Scutellaria prostrata Jacg. ex Benh. // Chem. Pharm. Bull. 1991. Vol. 39. Pp. 1466-1472.

95. Попова Т.П., Литвиненко В.И., Гордиенко В.Г., Пакалн Д.А. Хризин и его производные в растениях рода Scutellaria // Химия природных соединений. 1976. №6. С. 730-735.

96. Каримов А., Юлдашев М.П., Ботиров Э.Х. Флавоноиды Scutellaria haematochlora Juz. и S. ocellata Juz. // Химия растительного сырья. 2012. №3. С. 101-105.

97. Long H.L., Guo I.S., Den A.J., Lee J.H., Lin M., Lu Y., Zhang H. Zh., Feng W. F. Two new flavonoids from the roots of Scutellaria baicalensis // Journal of Asian Natural Products Research. 2015. Vol. 17, N7. Pp. 756-760.

98. Wang M.-H., Li L.-Zh., Sun J.-B., Liang J.-Y., Wu F.-H. A new antioxidant flavone glycoside from Scutellaria baicalensis Georgi. //Nat. Prod. Res. 2014. Vol. 28(20). Pp. 1772-1776.

99. Choi Y.O., Song H.-H., Kim Y.-M., Kang N.S., Han S-Y., Chin Y.-W. c-Met and ALK Inhibitory Constituents from Scutellaria baicalensis // Bulletin of the Korean Chemical Society. 2015. Vol. 36(1). Pp. 402-405.

100. Gong T., Wang Ch.-F, Yuan J.-R., Li Y., Gu J.-F., Zhao B.-J., Zhang L., Jia X.-B., Feng L., Liu Sh.-L. Inhibition of Tumor Growth and Immunomodulatory effects of Flavonoids and Scutebarbatines of Scutellaria barbata D. Don in Lewis-Bearing C57BL/6 Mice. // Evidence-based Complementary and Alternative Medicine. 2015. Article ID 630760. URL: http://dx.doi.org/10.1155/2015/630760

101. Wang Y., Xue X., Xiao Y., Zhang F., Xu Q., Liang X. Purification and preparation of compounds from an extract of Scutellaria barbata D. Don using preparative parallel high performance liquid chromatography // Journal of Separation Science. 2008. Vol. 31, N10. Pp. 1669-1676.

102. Delange D.M., Morales Rico C.L., Canavaciolo V.G., Cuellar A.C., Oliver E.S. Selective and High Yield Isolation of Pure Wogonin from Aerial Parts of Scutellaria havanensis Jacq. // International Journal of Pharmaceutical Sciences Review and Research. 2015. Vol. 30(2). Pp. 104-108.

103. Zhang Zh., He L., Lu L., Yuan Liu, Dong G., Miao J., Luo P. Characterization and quantification of the chemical compositions of Scutellariae Barbatae herba and differentiation from its substitute by combining UHPLC-PDAQTOF-MS/MS with UHPLC-MS/MS // Journal of Pharmaceutical and Biomedical Analysis. 2015. Vol. 109. Pp. 62-66.

104. He L., Zhang Zh., Lu L., Liu Y., Li Sh., Wang J., Song Zh., Yan Zh., Miao J. Rapid identification and quantitative analysis of the chemical Constituents in Scutellaria indica L. by UHPLC-QTOF-MS and UHPLC-MS/MS // Journal of Pharmaceutical and Biomedical Analysis. 2016. Vol. 117. Pp. 125-139.

105. Cuong T.D., Hung T.M., Lee J.-S., Weon K.-Y., Woo M.H., Min B.S. Anti-inflammatory activity of phenolic compounds from the whole plant of Scutellaria indica // Bioorganic and Medicinal Chemistry Letters. 2015. Vol. 25(5). Pp. 1129-1134.

106. Boozari M., Mohammadi A., Asili J., Emami S.A., Najaran Z. T. Growth inhibition and apoptosis induction by Scutellaria pinnatifida A. Ham. on HL-60 and K562 leukemic cell lines // Environmental Toxicology and Pharmacology. 2015. Vol. 39(1). Pp. 307-312.

107. Madani mousavi S.N., Delazar A., Nazemiyeh H., Khodaie L. Biological Activity and Phytochemical Study of Scutellaria platystegia // Iranian J. Pharm. Research. 2015. Vol. 14(1). Pp. 215-223.

108. Bhat G., Ganai B.A., Shawl A. S. New phenolics from the root of Scutellaria prostrata JACQ.ex BENTH. // Natural product research. 2014. Vol. 28(20). Pp. 1685-1690.

109. Joshee N.,Tascan A., Medina-Bolivar F., Parajuli P., Rimando A.M., Shannon D.A., Adelberg J.W. Scutellaria: Biotechnology, Phytochemistry and Its Potential as a Commerical Medicinal Crope // Biotechnology for Medicinal Plants: Micropropagation and Improvement. Springer-Verlag. Berlin Heidelberg. 2013. Pp. 69-100.

110. Nishikawa K., Furukawa H., Fujioka T. et al. Flavone production in transformed root culture of Scutellaria baicalensis Georgi. // Phytochemistry. 1999. Vol. 52. Pp. 885-890.

111. Nishikawa K., Ishimaru K. Flavonoids in root cultures of Scutellaria baicalensis // J. Plant Physiol. 1997. Vol. 151. Pp. 633-636.

112. Stojakowska A., Malarz J. Flavonoid production in transformed root cultures of Scutellaria baicalensis // Plant Physiol. 2000. Vol. 156. Pp. 121-125. 
113. Hirotani M., Nagashima S., Yoshikawa T. Baicalin and baicalein productions of cultured Scutellaria baicalensis cells // Natural Medicines. 1998. Vol. 52(5). Pp. 440-443.

114. Seo W.T., Park Y.H., Choe T.B. Identification and production of flavonoids in a cell suspension culture of Scutellaria baicalensis // Plant Cell Reports. 1993. Vol. 12. Pp. 414-417.

115. Zhou Y., Hirotani M., Yoshikawa T., Furuya T. Flavonoids and phenylethanoids from hairy root culture of Scutellaria baicalensis // Phytochemistry. 1997. Vol. 44. Pp. 83-87.

116. Kovács D., Kuzovkina I.N., Szöke É., Kursinszki L. HPLC determination of flavonoids in hairy-root culture of Scutellaria baicalensis Georgi. // Cromatographia. 2004. Vol. 60. Pp. 81-85.

117. Кузовкина И.Н., Гусева Н.В., Прокофьева М.Ю. Перспективы использования культивируемых in vitro корней шлемника байкальского как источника селективного цитотоксического флавона // Фенольные соединения: фундаментальные и прикладные аспекты: материалы докладов VIII междунар. симпозиума. М., 2012. С. 353 359.

118. Оленников Д.Н., Чирикова Н.К., Танхаева Л.М. Химический состав шлемника байкальского (Scutellaria baicalensis Georgi) // Химия растительного сырья. 2010. №2. С. 77-84.

Поступило в редакцию 16 декабря 2015 г.

После переработки 22 февраля 2016 г. 
Karimov A.M..$^{1,2}$, Botirov E.K. ${ }^{3 *}$ THE STRUCTURAL DIVERSITY AND STATE OF KNOWLEDGE OF FLAVONOIDS OF THE GENUS SCUTELLARIA L.

${ }^{I}$ Institute of Plant Chemistry of them. Acad. S.Y. Yunusov Academy of Sciences of the Republic of Uzbekistan, Mirzo Ulugbeka st., 77, Tashkent, 700170 (Republic of Uzbekistan)

${ }^{2}$ Namangan State University, Uichi st., 316, Namangan, 716001 (Republic of Uzbekistan)

${ }^{3}$ Surgut State University, Lenina st., 1, Surgut, 628412 (Russia), e-mail: botirov-nepi@mail.ru

The review presents the results of scientometric analysis of data on the level of study of flavo- noids of species of the genus Scutellaria L. of the world's flora, compiled information on hemia- trophia flavonoids. Presents data on the composition of flavonoids 63 species of skullcap, about distribution in plants, structure and sources 301 of flavonoids belonging to the groups of flavo- nes, flavanones, flavanonols, flavonols, chalcones, isoflavones, flavolignans and bioflavonoids. The greatest number of flavonoids isolated from plants of S. indica S. baicalensis, S. barbata, S. amoena, S. prastrata, S. galericulata, S. discolor, S. ramosissima and S. supina. Scientometric studies indicate the constantly growing interest in the study of species of the genus Scutellaria L. by scientists of various branches of science - phytochemical, biologists, pharmacologists, and others. Listed in the review information can be used to address issues of chemosystematic plants of the genus Scutellaria L.

Keywords: Scutellaria L., Lamiaceae, flavonoids, scientometric analysis, hemiatrophia.

\section{References}

1. Iuzepchuk S.V. Flora SSSR. [Flora of the USSR]. Moscow-Leningrad, 1954, vol. XX, pp. 72-225. (in Russ.).

2. Rod Scutellaria L. $\quad-$ shlemnik. [Scutellaria L. $\quad-$ skullcap.]. [Electronic resource]. URL: http://survinat.ru/2011/04/rod_scutellaria_1_-_shlemnik/\#ixzz1cFzg2tVm. (in Russ.).

3. Shlemnik baikal'skii (Scutellaria baicalensis). [Scutellaria baicalensis]. [Electronic resource]. URL: http://viktorovm.ru/vek-zdorovya-3/zdorovyj-son-ili-spokojstvie-dnem-i-nochyu/narodnyj-travnik/ (in Russ.).

4. Rastitel'nye resursy SSSR. Tsvetkovye rasteniia, ikh khimicheskii sostav, ispol'zovanie. Semeistva Hippuridaceae-Lobeliacae. [Plant resources of the USSR. Flowering plants, their chemical composition, the use. Families Hippuridaceae-Lobeliacae]. St. Petersburg, 1991, pp. 85-90. (in Russ.).

5. Aseeva T.A., Batuev B.B., Khankin I.S., Fedotovskikh H.H., Dashnev D.B. Rastitel'nye resursy, 1985, vol. 21, issue 1, pp. 15-25. (in Russ.).

6. Ibragimov F.I., Ibragimova B.C. Osnovnye lekarstvennye sredstva kitaiskoi meditsiny. [Essential medicines Chinese medicine]. Moscow, 1960, 412 p. (in Russ.).

7. Minaeva V.G. Shlemnik baikal'skii Scutellaria baicalensis Georgi. Lekarstvennye rasteniia Sibiri. [Baikal skullcap Scutellaria baicalensis Georgi. Medicinal Plants of Siberia.]. Novosibirsk, 1991, pp. 212-214. (in Russ.).

8. Shang X., He X., He X., Li M., Zhang R., Fan P., Zhang Q., Jia Z. J. Ethnopharmacol., 2010, vol. 128, pp. $279-313$.

9. Gol'dberg E.D., Dygai A.M., Litvinenko V.I., Popova T.P., Suslov N.I. Shlemnik baikal'skii. Fitokhimiia $i$ farmakologicheskie svoistva. [Baikal skullcap. Phytochemistry and pharmacological properties]. Tomsk, 1994, 222 p. (in Russ.).

10. Chemesova I.I. Rastitel'nye resursy, 1993, vol. 29, issue 2, pp. 89-99. (in Russ.).

11. Olennikov D.N., Chirikova N.K. Chem. Nat. Comp., 2013, vol. 49, pp. 124-126.

12. Atlas arealov i resursov lekarstvennykh rastenii. [Atlas of areas and resources of medicinal plants]. Moscow, 1976, 340 p. (in Russ.).

13. Litvinenko V.I., Popova T.P., Volovik V.G., Gol'dberg E.D., Dygai A.M., Suslov N.I. Fitokhimiia $i$ farmakologicheskie svoistva preparatov shlemnika baikal'skogo. [Phytochemistry and pharmacological properties of drugs of Baikal skullcap]. Kharkiv, 2007, 763 p. (in Russ.).

14. Chirikova N.K., Olennikov D.N., Tankhaeva L.M. Khimiia rastitel'nogo syria, 2009, no. 1, pp. 73-78. (in Russ.).

15. Tarakhovskii Iu.S., Kim Iu.A., Abdrasilov B.S., Muzafarov E.N. Flavonoidy: biokhimiia, biofizika, meditsina. [Flavonoids: biochemistry, biophysics, medicine]. Pushchino, 2013, 310 p. (in Russ.).

16. Parajuli P., Joshee N., Rimando A., Mittal S., Yadav A.K. Planta Med., 2009, vol. 75, pp. 41-48.

17. Li-Weber M. Cancer Treat. Rev., 2009, vol. 35, pp. 57-68.

18. Yu, J.Q., Liu, H.B., Lei, J.C., Tan, W.J., Hu, X.M., Zou, G.L. Phytotherapy Research., 2007, vol. 21, pp. 817-822.

19. Sonoda M., Nishiyama T., Matsukawa Y., Moriyasu M. J. Ethnopharmacol., 2004, vol. 91, pp. 65-68.

20. Gao Z., Huang K., Yang X., Xu H. Biochim. Biophys. Acta., 1999, vol. 1472, no. 3, pp. 643-650.

21. Park H.G., Yoon S.Y., Choi J.Y., Lee G.S., Choi J.H., Shin C.Y., Son K.H., Lee, Y.S., Kim, W.K., Ryu J.H., Ko K.H., Cheong J.H. European J. Pharmacology, 2007, vol. 574, pp. 112-119.

22. Flora Uzbekistana. [Flora of Uzbekistan]. Tashkent, 1961, vol. 5, pp. 270-284. (in Russ.).

23. Olennikov D.N., Chirikova N.K., Tankhaeva L.M. Khimiia rastitel'nogo syr'ia, 2009, no. 4, pp. 89-98. (in Russ.).

24. Mamadalieva N.Z., Herrmann F., El-Readi M.Z., Tahrani A., Hamoud R., Egamberdieva D.R., Azimova S.S., Wink M. J. Pharm. Pharmacol., 2011, vol. 63, no. 10, pp. 1346-1357.

25. Malikov V.M, Iuldashev M.P. Khimiia prirodnykh soedinenii, 2002, no. 4, pp. 299-324; 2002, no. 5, pp. $385-407$. (in Russ.).

\footnotetext{
* Corresponding author.
} 
26. Kutsyk A.V., Sereda A.V., Popova T.P., Rybachenko A.I., Litvinenko V.I. Farmakom, 1998, no. 2, pp. 18-20. (in Russ.).

27. Chirikova N.K., Olennikov D.N., Tankhaeva L.M. Khimiia rastitel'nogo syr'ia, 2009, no. 4, pp. 99-105. (in Russ.).

28. Rastitel'nye resursy Rossii i sopredel'nykh gosudarstv. [Plant Resources of Russia and neighboring countries]. St. Petersburg, 1996, pp. 303-304. (in Russ.).

29. Valant-Vetschera K.M., Wollenweber E. Flavonoids. Chemistry, Biochemistry and Application. Ed. by Andersen Q.M., Markham K.R. New-York: Taylor and Francis Group. 2006, pp. 617-748.

30. Kikuchi Y., Miyaichi Y., Yamagnchi Y., Kizu H., Tomimori T., Vetschera K. Chem.Pharm. Bull., 1991, vol. 39, pp. 199-201.

31. Zhou Z.H., Zhang Y.J., Yang Ch. R. New flavonoid glycosides from Scutellaria amoena. Advances in Plant Glycosides, Chemistry and Biology. Amsterdam: Elsevier. 1999, pp. 305-310.

32. Iuldashev M.P., Batirov E.Kh., Malikov V.M. Khimiia prirodnykh soedinenii, 1996, no. 4, pp. 610-612. (in Russ.).

33. Tomimori T., Miyaichi Y., Imoto Y.Kizu H., Namba T. Chem. Pharm. Bull., 1988, vol. 36, pp. 3654-3658.

34. Popova T.P., Pakaln D.A., Litvinenko V.I. Khimiia prirodnykh soedinenii, 1975, no. 1, pp. 97-98. (in Russ.).

35. Dudetskaia N.A., Teslov L.S., Anisimova N.A. Rastitel'nye resursy, 2010, vol. 52, issue 1, pp. 125-143. (in Russ.).

36. Dudetskaia N.A., Teslov L.S., Sipkina N.Iu. Rastitel'nye resursy, 2011, vol. 59, issue 4, pp. 96-106. (in Russ.).

37. Iuldashev M.P. Malikov V.M. Khimiia prirodnykh soedinenii, 1993, no. 3, pp. 471. (in Russ.).

38. Kikuchi Y., Miyaichi Y., Tomimori T. Chem. Pham. Bull., 1991, vol. 39, pp. 1051-1054.

39. Tashmatov Z.O., Eshbakova K.A. Fenol'nye soedineniia: fundamental'nye i prikladnye aspekty: materialy dokladov VIII mezhd. simp. [Phenolic compounds: fundamental and applied aspects: materials of VIII International Symposium]. Moscow, 2012, pp. 668-675. (in Russ.).

40. Kamoldinov Kh.Sh., Eshbakova K.A., Bobakulov Kh.M. Chem. Nat. Comp., 2012, vol. 48, pp. 889-890.

41. Miyaichi Y., Imoto Y., Tomimori T. Lin C-C. Chem. Pharm. Bull., 1987, vol. 35, pp. 3720-3725.

42. Iuldashev M.P., Karimov A. Khimiia prirodnykh soedinenii, 2005, no. 1, pp. 26-28. (in Russ.).

43. Hussain H., Ahmad V.U., Anwar S., Miana G.A., Krohn K. Biochem. Syst. Ecol., 2008, vol. 36, pp. 490-492.

44. Oganesyan G.B. Chem. Nat. Comp., 2010, vol. 46, pp. 466-467.

45. Siddikov G.U., Iuldashev M.P., Aripova C.F., Vdovin A.D., Abdullaev N.D., Botirov E.Kh. Khimiia prirodnykh soedinenii, 2008, no. 1, pp. 24-25. (in Russ.).

46. Davydov V.S., Nikitina G.K., Bandiukova V.A. Rastitel'nye resursy, 1991, vol. 27, issue 2, pp. 50-54. (in Russ.).

47. Nasrullaev F.D. Flavony nekotorykh vidov Scutellaria i Lagochilus semeistvo Labiatae : avtoref. diss. ... kand. khim. nauk. [Flavones and some species of Scutellaria Lagochilus family Labiatae: the dissertation author's Candidate of Chemical Science]. Tashkent, 1993, 24 p. (in Russ.).

48. Muradov R., Abdullaev Sh. V. Khimiia prirodnykh soedinenii, 1990, no. 4, pp. 546-547. (in Russ.).

49. Miyaichi Y., Morimoto T., Yaguchi K., Kizu H. J. Nature Medicine, 2006, vol. 60, pp. 157-158.

50. Popova T.P., Pakaln D.A., N.A.Chernykh, I.G.Zos, Litvinenko V.I. Rastitel'nye resursy, 1976, vol. 12, no. 2, pp. 232-236. (in Russ.).

51. Chirikova N.K., Olennikov D.N. $X^{\text {th }}$ Inter. Symp. on the Chemistry of Natur. Compounds: Abstracts. Tashkent Bukhara, 2013. P. 367.

52. Tashmatov Z.O., Eshbakova K.A., Bobakulov Kh.M., Abdullaev N.D. Khimiia prirodnykh soedinenii, 2009, no. 6, pp. 737-738. (in Russ.).

53. Wang H.Y., Xiao L.H., Liu L. J. Shenyang Pharm. University, 2003, vol. 20, pp. 399-403.

54. Chemesova I.I., Iinuma M., Budantsev A.L. Chem. Nat. Comp., 1993, vol. 29, pp. 133-134.

55. Karimov A.M., Iuldashev M.P., Botirov E.Kh. Khimiia rastitel'nogo syr'ia, 2015, no. 1, pp. 63-68. (in Russ.).

56. Iuldashev M.P., Batirov E.Kh., Malikov V.M. Khimiia prirodnykh soedinenii, 1996, no. 4, pp. 610-612. (in Russ.).

57. Wang Y.Q., Matsuzaki K., Takahashi K., Okuyama T., Shibata S. Chem. Pharm. Bull., 1988, vol. 36, pp. 3206-3209.

58. Wang Y.Q., Matsuzaki K., Takahashi K., Okuyama T., Shibata S. Acta Pharm. Sinica, 1991, vol. 26(5), pp. 358-361.

59. Iuldashev M.P. Khimiia prirodnykh soedinenii, 2001, no. 5, pp. 364-366. (in Russ.).

60. Zhang Y.Y., Guo Y.Z., Ageta H., Harigaya Y., Onda M., Hashimoto K., Ikeya Y., Okada M., Maruno M. J. Chinese Pharm. Sciences, 1998, vol. 7(2), pp. 100-102.

61. Iuldashev M.P., Batirov E.Kh., Malikov V.M. Khimiia prirodnykh soedinenii, 1992, no. 2, pp. $178-182$. (in Russ.).

62. Tashmatov Z.O., Eshbakova K.A., Bobakulov Kh.M. Khimiia prirodnykh soedinenii, 2011, pp. 392-393. (in Russ.).

63. Siddikov G.U., Iuldashev M.P., Abdullaev Sh.V. Khimiia prirodnykh soedinenii, 2007, no. 3, pp. 270-271.

64. Eshbakova K.A., Toshmatov Z.O., Yili A., Aisa H.A., Abdullaev N.D. Chem. Nat. Comp., 2013, vol. 49, pp. 103-105. 
65. Tashmatov Z.O., Eshbakova K.A., Bobakulov Kh.M. Khimiia prirodnykh soedinenii, 2011, pp. 487-488. (in Russ.).

66. Yu J.Q., Liu H.B., Lei J.C., Tan W.J., Hu X.M., Zou G.L. Phytotherapy Research, 2007, vol. 21, pp. 817-822.

67. Awad R., Arnason J.T., Trudeau V., Bergeron C., Budzinski J.W., Foster B.C., Merali Z. Phytomedicine, 2003, vol. 10, pp. 640-649.

68. Zhang, Z.Z., Lian, X.Y., Li, S.Y., Stringer, J.L. Phytomedicine, 2009, vol. 16, pp. 485-493.

69. Zhang Y.Y., Guo Y.Z., Ageta H., Harigaya Y., Onda M., Hashimoto K., Ikeya Y., Okada M., Maruno M. Planta Medica, 1997, vol. 63(6), pp. 536-539.

70. Miyaichi Y., Ishii K., Kuno T., Tomimori T. Natrual Medicines, 1999, vol. 53, pp. 237-241.

71. Iuldashev M.P., Botirov E.Kh., Malikov V.M. Khimiia prirodnykh soedinenii, 1994, no. 6, pp. 822-823. (in Russ.).

72. Ismailov A.I., Karimzhonov A.K., Khudaibergenov T., Litvinenko V.I., Popova T.P. Khimiia prirodnykh soedinenii, 1995, no. 3, pp. 500-501. (in Russ.).

73. Karimov A., Iuldashev M.P. Khimiia prirodnykh soedinenii, 2001, no. 5, pp. 367-369. (in Russ.).

74. Tomimori T., Imoto Y., Miyaichi Y. Chem. Pharm. Bull., 1990, vol. 38, pp. 3488-3490.

75. Iuldashev M.P., Batirov E.Kh., Nigmatullaev A., Malikov V.M. Khimiia prirodnykh soedinenii, 1994, no. 3, pp. 355-359.

76. Miyaichi Y., Imoto Y., Tomimori T., Namba T. Chem. Pharm. Bull., 1988, vol. 36, pp. 2371-2376.

77. Tomimori T., Miyaichi Y., Imoto Y., Kizu H., Namba T. Chem. Pharm. Bull., 1986, vol. 34, pp. 406-408.

78. Karimov A., Murodov R., Abdullaev Sh.V., Popova T.P., Litvinenko V.I. Khimiia prirodnykh soedinenii, 1999, special issue, pp. 45-46. (in Russ.).

79. Karimov A., Iuldashev M.P., Abdullaev Sh.V., Botirov E.Kh. Khimiia prirodnykh soedinenii, 2000, special issue, pp. 18-19. (in Russ.).

80. Miyaichi Y., Hanamitsu E., Kizu H., Tomimori T. Chem. Pharm. Bull., 2006, vol. 54, pp. 435-441.

81. Miyaichi Y., Imoto Y., Tomimori T. Lin C-C. Chem. Pharm. Bull., 1987, vol. 35, pp. 3720-3725.

82. Miyaichi Y., Kizu H., Tomimori T., Lin C.C. Chem. Pharm. Bull., 1989, vol. 39, pp. 794-797.

83. Makino T., Hishida A., Goda Y., Mizukami H. J. Nature Medicine, 2008, vol. 62, pp. 294-299.

84. Iuldashev M.P. Khimiia prirodnykh soedinenii, 1999, no. 2, pp. 239-240. (in Russ.).

85. Chemesova I.I., Iinuma M., Budantsev A.L., Anokhina B.O. Rastitel'nye resursy, 1993, vol. 29, issue 4, pp. 75. (in Russ.).

86. Chemesova I.I., linuma M., Budantsev A.L., Anokhina B.O. Rastitel'nye resursy, 1994, vol. 30, no. 1-2, pp. 78. (in Russ.).

87. Iuldashev M.P., Batirov E.Kh., Malikov V.M. Khimiia prirodnykh soedinenii, 1995, no. 2, pp. 317-318. (in Russ.).

88. Ersöz T., Harput Ü.Ş., Saracoğlu İ., çaliş İ., Ogihara Y. Turk J. Chem., 2002, vol. 26, pp. 581-588.

89. Chemesova I.I., Budantsev A.L. Khimiia prirodnykh soedinenii, 1994, no. 2, pp. 287-288. (in Russ.).

90. Tomimori T., Miyaichi Y., Imoto Y., Kizu H., Namba T. Chem. Pharm. Bull., 1985, vol. 33, pp. 4457-4463.

91. Zhou Z.H., Yang C.R. Acta Botanica Yunnanica, 2000, vol. 22, pp. 475-481.

92. Wang G., Wang F., Liu J.-K. Molecules, 2011, vol. 16, pp. 1402-1408.

93. Siddikov G.U., Iuldashev M.P., Botirov E.Kh., Abdullaev Sh.V. Khimiia prirodnykh soedinenii, 2006, no. 3, pp. 293. (in Russ.).

94. Kikuchi Y., Miyaichi Y., Tomimori T. Chem. Pharm. Bull., 1991, vol. 39, pp. 1466-1472.

95. Popova T.P., Litvinenko V.I., Gordienko V.G., Pakaln D.A. Khimiia prirodnykh soedinenii, 1976, no. 6, pp. 730-735.

96. 96. Karimov A., Iuldashev M.P., Botirov E.Kh. Khimiia rastitel'nogo syr'ia, 2012, no. 3, pp. 101-105.

97. Long H.L., Guo I.S., Den A.J., Lee J.H., Lin M., Lu Y., Zhang H. Zh., Feng W. F. Journal of Asian Natural Products Research, 2015, vol. 17, no. 7, pp. 756-760.

98. Wang M.-H., Li L.-Zh., Sun J.-B., Liang J.-Y., Wu F.-H. Nat. Prod. Res., 2014, vol. 28(20), pp. 1772-1776.

99. Choi Y.O., Song H.-H., Kim Y.-M., Kang N.S., Han S-Y., Chin Y.-W. Bulletin of the Korean Chemical Society, 2015, vol. 36(1), pp. 402-405.

100. Gong T., Wang Ch.-F, Yuan J.-R., Li Y., Gu J.-F., Zhao B.-J., Zhang L., Jia X.-B., Feng L., Liu Sh.-L. Evidence-based Comple- mentary and Alternative Medicine, 2015. Article ID 630760. URL: http://dx.doi.org/10.1155/2015/630760

101. Wang Y., Xue X., Xiao Y., Zhang F., Xu Q., Liang X. Journal of Separation Science, 2008, vol. 31, N10, pp. 1669-1676.

102. Delange D.M., Morales Rico C.L., Canavaciolo V.G., Cuellar A.C., Oliver E.S. International Journal of Pharmaceutical Sciences Review and Research, 2015, vol. 30(2), pp. 104-108.

103. Zhang Zh., He L., Lu L., Yuan Liu, Dong G., Miao J., Luo P. Journal of Pharmaceutical and Biomedical Analysis, 2015, vol. 109, pp. 62-66.

104. He L., Zhang Zh., Lu L., Liu Y., Li Sh., Wang J., Song Zh., Yan Zh., Miao J. Journal of Pharmaceutical and Biomedical Analysis, 2016, vol. 117, pp. 125-139.

105. Cuong T.D., Hung T.M., Lee J.-S., Weon K.-Y., Woo M.H., Min B.S. Bioorganic and Medicinal Chemistry Letters, 2015, vol. 25(5), pp. 1129-1134. 
106. Boozari M., Mohammadi A., Asili J., Emami S.A., Najaran Z. T. Environmental Toxicology and Pharmacology, 2015, vol. 39(1), pp. 307-312.

107. Madani mousavi S.N., Delazar A., Nazemiyeh H., Khodaie L. Iranian J. Pharm. Research, 2015, vol. 14(1), pp. 215-223.

108. Bhat G., Ganai B.A., Shawl A.S. Natural product research,. 2014, vol. 28(20), pp. 1685-1690.

109. Joshee N.,Tascan A., Medina-Bolivar F., Parajuli P., Rimando A.M., Shannon D.A., Adelberg J.W. Biotechnology for Medicinal Plants: Micropropagation and Improvement. Springer-Verlag. Berlin Heidelberg. 2013, pp. 69-100.

110. Nishikawa K., Furukawa H., Fujioka T. et al. Phytochemistry, 1999, vol. 52, pp. 885-890.

111. Nishikawa K., Ishimaru K. J. Plant Physiol., 1997, vol. 151, pp. 633-636.

112. Stojakowska A., Malarz J. Plant Physiol., 2000, vol. 156, pp. 121-125.

113. Hirotani M., Nagashima S., Yoshikawa T. Natural Medicines, 1998, vol. 52(5), pp. 440-443.

114. Seo W.T., Park Y.H., Choe T.B. Plant Cell Reports, 1993, vol. 12, pp. 414-417.

115. Zhou Y., Hirotani M., Yoshikawa T., Furuya T. Phytochemistry, 1997, vol. 44, pp. 83-87.

116. Kovács D., Kuzovkina I.N., Szöke É., Kursinszki L. Cromatographia, 2004, vol. 60, pp. 81-85.

117. Kuzovkina I.N., Guseva N.V., Prokof'eva M.Iu. Fenol'nye soedineniia: fundamental'nye i prikladnye aspekty: materialy dokladov VIII mezhdunar. simpoziuma. [Phenolic compounds: fundamental and applied aspects: materials of VIII International Symposium]. Moscow, 2012, pp. 353-359. (in Russ.).

118. Olennikov D.N., Chirikova N.K., Tankhaeva L.M. Khimiia rastitel'nogo syr'ia, 2010, no. 2, pp. 77-84. (in Russ.).

Received December 16, 2015

Revised February 22, 2016 